\title{
Öğretmen Eğitimi Sürecinin Bilişim Teknolojileri Öğretmen Adaylarının Mesleki Kimlikleri Üzerindeki Etkisi
}

\begin{tabular}{lccc}
\hline MAKALE TÜRÜ & Başvuru Tarihi & Kabul Tarihi & Yayın Tarihi \\
Araştırma Makalesi & 07.01 .2019 & 30.04 .2019 & 01.05 .2019 \\
\hline
\end{tabular}

Deniz Atal

Ankara Üniversitesi

\begin{abstract}
Öz
$\mathrm{Bu}$ araştırmanın amacı, öğretmen eğitimi sürecinin Bilişim Teknolojileri (BT) öğretmen adaylarının mesleki kimlikleri üzerindeki etkisini incelemektir. Nitel araştırma desenlerinden temel yorumlayıcı desen kullanılarak gerçekleştirilen araştırmaya Ankara Üniversitesi, Hacettepe Üniversitesi ve Gazi Üniversitesi Bilgisayar ve Öğretim Teknolojileri Eğitimi Programında 2016-2017 öğretim yılında öğrenim görmekte olan 36 öğretmen adayı katılmıştır. Öğretmen adayları amaçlı örnekleme yöntemi kullanılarak belirlenmiştir. Bu öğretmen adaylarından 13'ü Ankara Üniversitesinde, 13'ü Hacettepe Üniversitesinde, 10'u ise Gazi Üniversitesinde öğrenim görmektedir. Katılımcıların 12'si erkek, 24'ü kadındır. Araştırmanın verileri araștırmacı tarafından geliștirilen yarı yapılandırılmıș görüşme formu ile toplanmıș ve tümevarımsal içerik analizi kullanılarak çözümlenmiştir. Sonuçlar göstermiş̧ir ki araştırmaya katılan BT öğretmen adaylarının yarısından fazlası öğretmenliğini yapmak üzere mezun oldukları BT alanını ve BT öğretmenlerinin kim olduklarını açık bir biçimde tanımlayamamaktadır. Kendilerini mesleğini sürdürme konusunda yeterli, özgüvenli ve istekli hissetmeyen BT öğretmen adayları, aldıkları eğitimin kendilerini iyi bir BT ögrretmeni olarak görmeleri için yeterli olmadığını düşünmektedirler. Öte yandan, katılımcıların geliştirmiş olduğu mesleki kimlikler üzerinde öğretmen eğitimi sürecinde aldıkları eğitimin niteliğinin, öğretim üyeleri ile kurulan iletişim ve etkileşimin, okul deneyimi sürecinin ve sağlanan kurumsal desteğin önemli etkileri olduğu belirlenmiştir. Araştırma ile ulaşılan sonuçlara dayalı olarak BT öğretmen adaylarının mesleki yetersizlik algısı ve olumsuz mesleki kimlik ile mezun olmamaları için yapılması gerekenler tartışılmıştır.
\end{abstract}

Anahtar sözcükler: Mesleki kimlik, ögretmen eğitimi, profesyonel gelișim, bilișim teknolojileri öğretmen adayları.

${ }^{1}$ Sorumlu Yazar: Arş. Gör. Dr., Eğitim Bilimleri Fakültesi, Bilgisayar ve Öğretim Teknolojileri Eğitimi Bölümü, Bilgisayar ve Öğretim Teknolojileri Eğitimi Anabilim Dalı, E-posta: atal@ankara.edu.tr, https://orcid.org/0000-0001-8030-9996 
Bilişim Teknolojileri (BT) öğretmenleri, okullarda eğitim daha etkili ve nitelikli duruma nasıl getirilebilir sorusuna yanıt arayan, teknolojinin doğru yer ve zamanda etkili bir biçimde kullanımını sağlayan, teknoloji ile ilgili temel becerileri öğrencilere ve öğretmenlere kazandıran rehber öğretmenler olarak bilinmektedir. Alanyazında öğretim teknoloğu, eğitim teknoloğu, teknoloji öğreticisi, teknoloji koordinatörü ve teknoloji uzmanı gibi (Alkan, 1997; Sugar, 2005; Surry ve Robinson, 2001; Tennyson, 2001) farklı isimlerle anılsa da BT öğretmenleri/öğretim teknologları; teknoloji tabanlı öğrenme ortamlarındaki gereksinimlerle başa çıkabilmek için öğretim tasarımı süreçlerini yürüten, başarım sorunlarını çözen, öğrencilere ve öğretmenlere gerekli yardımı ve desteği sağlayan öncelikli kişilerdir (Tennyson, 2001). BT öğretmenlerinin üstlendikleri bu görev ve sorumluluklar, onların teknolojinin etkili ve verimli kullanımı ile ilgili temel becerilerin kazandırılmasında ve teknolojinin eğitime kaynaştırılmasında anahtar bir role ve öneme sahip olduğunu göstermektedir. Alanyazında pek çok araştırmada da BT öğretmenlerinin değişim ajanları/aracıları, teknoloji liderleri ve teknoloji koçları olarak vurgulanması onların sahip olduğu önemi ortaya koymaktadır (Avidov-Ungar ve Shamir-Inbal, 2017; Devolder, Vanderlinde, Braak ve Tondeur, 2010; Frazier ve Bailey, 2004; Marcovitz, 2000; Sugar, 2005).

Teknoloji liderleri olarak bilinen BT öğretmenlerini, çalıştıkları kurumlarda var olan kaynakların erişimini sağlamaktan ortaya çıkan teknik sorunlara çözüm bulmaya kadar farklı pek çok görev beklemektedir (Avidov-Ungar ve Shamir-Inbal, 2017; Frazier ve Bailey, 2004; Sugar, 2005; Sugar ve Holloman, 2009; Woo, 2015). Örneğin Woo’ya (2015) göre, BT koordinatörleri okullarda bilgi ve iletişim teknolojilerinin (BİT) altyapısını kurmak ve BİT'in etkili kullanımında öğrencilere ve öğretmenlere pedagojik (eğitim bilimsel) ve teknik destek sağlamaktan sorumludur. Ancak BT öğretmenleri/koordinatörleri bu görev ve sorumluluklar arasından en fazla teknik destek sağlama boyutu ile ilgilenmek zorunda kalmaktadırlar (Devolder ve diğ., 2010; Lai ve Pratt, 2004; Rodríguez-Miranda, Pozuelos-Estrada ve León-Jariego, 2014). Örneğin Rodríguez-Miranda ve diğ. (2014) araştırmalarında BT koordinatörlerinin deneyimleri olup olmadığına bakılmaksızın; elektronik cihazların bakımını yapmak, okullarda yaşanılan teknik sorunlara çözüm bulmak ve öğretmenlere teknik konularda rehberlik etmek gibi görevlere çok fazla zaman ayırdıklarını ve bu görevlerin onların birincil görevlerinin önüne geçtiğini belirlemişlerdir. Benzer biçimde Avidov-Ungar ve Shamir-Inbal (2017) da BT öğretmenlerinin/koordinatörlerinin; (a) teknolojik bilgi, (b) pedagojik bilgi, (c) kurumsal bilgi ve (d) liderlik bilgisine sahip olması gerektiğini ancak çoğunlukla teknolojik bilgiyi işe koşan görevlerle uğraşmak zorunda olduklarını vurgulamışlardır.

Türkiye'de de BT öğretmenleri; bilgisayar öğretmeni, bilişim teknolojileri öğretmeni, bilgisayar koordinatör öğretmeni, bilgisayar formatör öğretmeni, bilişim teknolojileri rehber öğretmeni, Fatih Projesi BT rehber öğretmeni gibi farklı isimlerle görevlerini yerine getirmişlerdir. Yıllar içinde bu öğretmenler bir yandan alanlarında sürekli yapılan değişim ve düzenlemelerle uğraşırken, öbür yandan pek çok ülkede olduğu gibi okullarda öğretimle ilgili-ilgisiz pek çok sorumlulukla karşı karşıya 
kalmışlardır. BT öğretmenlerinin üstlenmek zorunda kaldıkları görev ve sorumluluklar nedeni ile yaşadıkları sorunlar yıllardır pek çok araştırmada tartışılmıştır (Atal-Köysüren ve Deryakulu, 2017; Deryakulu, 2005, 2006; Deryakulu ve Olkun, 2007; Durak ve Seferoğlu, 2017; Dursun, 2015; Eren ve Uluuysal, 2012; Karal ve Timuçin, 2010; Karataş, 2010; Önal, 2018; Şahinkayası, Kelleci ve Şahinkayası, 2013; Şerefoğlu-Henkoğlu ve Yıldırım, 2012; Topu ve Göktaş, 2012). Örneğin, Şahinkayası ve diğ.'ne (2013) göre BT öğretmenleri görev tanımlarında yaşadıkları belirsizlikler nedeni ile okullarda bilgisayarla ilişkili olabilecek her türlü sorumluluğu üstlenmek ve sorunlara çözüm bulmak gibi görevleri yerine getirmek zorunda kalmaktadırlar. Dursun (2015) da BT öğretmenlerinin okullarda dersle ilgili beklentilerle uğraşmak yerine ders dişı teknik beklentileri karşılamak zorunda kaldıklarını, bu nedenle kendilerini öğretmenden çok bilgisayar teknisyeni, teknik eleman, teknisyen, tamirci gibi tanımladıklarını belirtmiştir. Okullarda yaşanılan bu olumsuz durumlar nedeni ile BT öğretmenleri, daha nitelikli öğretimi nasıl sağlayabilecekleri konusunda tartışmak yerine, yaşadıkları sorunlar arasında kaybolmaktadır. Ortaya çıkan bu durum, onlarda üretkenlik eksikliği, duygusal tükenme, iş doyumsuzluğu, kurumsal bağl1lık eksikliği (Atal-Köysüren, 2016; AtalKöysüren ve Deryakulu, 2017; Devolder ve diğ., 2010; Deryakulu, 2005, 2006; Karal ve Timuçin, 2010; Topu ve Göktaş, 2012; Yeşiltepe ve Erdoğan, 2013) ve özellikle mesleki kimlik sorunlarına neden olmaktadır (Atal-Köysüren, 2016).

Mesleki kimlik kavramı, öğretmenlerin mesleki gelişimlerini ve yaşantılarını anlama, öğretmen olarak niteliklerini belirleme, bağlılıklarını ve kariyer kararlarını yorumlamada oldukça önemli bir kavram olarak ortaya çıkmaktadır (Day, Elliot ve Kington, 2005; Hong, 2010; Korthagen, 2004). Öğretmenlik mesleği temel alındığında mesleki kimlik; bireyin kendisini öğretmen olarak nasıl gördüğü, öğretmen olarak kendisi hakkındaki bilgisi ve öğretmenlik mesleğine yönelik algıları olarak tanımlanmaktadır (Beijaard, Meijer ve Verloop, 2004; Bullough, 1997; Bullough ve Knowles, 1991). Sahip olunan mesleki kimlik ile ilgili algıların temelinde pek çok bireysel ve bağlamsal değişken yer almaktadır. Alanyazında farklı araştırmalarda bu değişkenler; yeterlikler, güdülenmeler, duygular, inançlar, değerler, görev ve sorumluluklar, mesleki bağlılık ve geleceğe bakış biçiminde ele alınmaktadır (Hong, 2010; Kelchtermans, 1993; Lasky, 2005; Sutherland, Howard ve Markauskaite, 2010; van Veen ve Sleegers, 2006; Zembylas, 2003). Her ne kadar bu özellikler mesleki kimliğin bireysel yönüne dikkati çekse de toplumsal ve bağlamsal özelliklerin de öğretmenlerin mesleki kimlikleri üzerindeki etkisi oldukça fazladır (Flores ve Day, 2006; Geijsel ve Meijers, 2005; Hong, 2010). Örneğin, içinde bulunulan toplumsal çevre, öğretmen eğitimi süreci, çalışılan kurum, yapılan politik değişim ve düzenlemeler, öğrenciler, öğretmenler ve yöneticilerle kurulan iletişim ve etkileşimler mesleki kimliği oldukça etkilemektedir (Beijaard ve diğ., 2004; Carter ve Doyle, 1996; Coldron ve Smith, 1999; Gee, 2000; Izadinia, 2013; Korthagen, 2004). Chong, Low ve Goh'a (2011) göre mesleki kimliğin yapılanması ve gelişimi, meslek öncesinde başlayan, alınan eğitimlerle biçimlenen, mesleğe giriş ile evrimleşen ve birey meslekle özdeşleştikçe gelişmeye devam eden bir bireysel olgunlaşma sürecidir. 
$\mathrm{Bu}$ sürece; önceki bireysel ve profesyonel deneyimler, mesleğe geliş nedenleri, öğretmen eğitiminde edinilen deneyimler ve kariyer planlarına kadar tüm süreçler karşılıklı etkileşimle etki etmektedir (Olsen, 2008).

Öğretmenlerin mesleki kimlik gelişimini etkileyen değişkenler arasında öğretmen eğitimi sürecinin yeri oldukça önemlidir (Beauchamp ve Thomas, 2009; Bullough, 1997; Ezer, Gilat ve Sagee, 2010; Izadinia, 2013; Rodgers ve Scott, 2008; Schepens, Aelterman ve Vlerick, 2009; Olsen, 2008). Pek çok araştırmacıya göre, öğretmen eğitimi programları hem mesleki kimlik gelişimi için gereksinimlerin belirlenmesinde hem de mesleki kimliğin devam eden gelişim sürecinde önemli bir başlangıç noktasını oluşturmaktadır (Bullough, 1997, Rodgers ve Scott, 2008; Hill, 2017). Ivanova ve Skara-MincLne'ye (2016) göre öğretmen eğitimi sürecinde öğrenme; kimlik oluşumu süreci olarak tanımlanmaktadır ve bu süreçte adaylar mesleğin temsilcisi olarak kendilerini ve mesleklerini kavramsallaştırmakta, profesyonel hedef ve isteklerini biçimlendirmektedirler. Bu biçimlendirme sürecine, öğretmen adaylarının içinde bulundukları eğitimsel bağlam (öğretmen eğitim programları ve uygulama ortamları), katıldıkları öğrenme toplulukları, kurdukları iletişim ve etkileşimler, sahip oldukları önceki deneyimler, öğretim üyelerinin nitelikleri gibi pek çok özellik etki etmektedir (Izadinia, 2013; Olsen, 2008).

Şu bir gerçektir ki belirli bir beklenti, düşünce ve amaçla geldikleri öğretmen eğitimi sürecinde adaylar, öğretim üyelerinden kuramsal ve uygulama bilgisi elde ederler (Hill, 2017; Sexton, 2008; van Lankveld, Schoonenboom, Volman, Croiset ve Beishuizen, 2017) ve elde edilen bu bilgi ve becerilerle alanları ve meslekleri ile ilgili farkındalıklarını, yeterliklerini ve deneyimlerini geliştirirler (Rodgers ve Scott, 2008; Walkington, 2005). Bu süreçte neler öğrendikleri ve deneyimledikleri, kendilerini nasıl gördükleri ve hissettikleri, nasıl iletişim ve etkileşim kurdukları öğretmen adaylarının mesleklerini, rollerini ve sorumluluklarını yani mesleki kimliklerini anlamlandırmalarına etki etmektedir (Alsup, 2006, Chang-Kredl ve Kingsley, 2014; Hong, Greene ve Lowery, 2017; Walkington, 2005). Son yıllardaki araştırmalarda da nitelikli öğretmenler yetiştirmek için odağın pedagojik bağlam yerine öğretmen adaylarının mesleki kimlik gelişimine ve bu gelişime etki eden değişkenlere kaydığ dikkati çekmektedir (Beauchamp ve Thomas, 2009; Hill, 2017; Ruohotie-Lyhty, 2013; Sexton, 2008; van Lankveld ve diğ., 2017).

BT öğretmen adaylarının öğretmen eğitimi sürecinde geliştirdikleri mesleki kimlik yapıları, meslek yaşantılarında yapılandırmaya devam edecekleri kimliğin temelini oluşturmaktadır. Bu bağlamda BT öğretmen adaylarının öğretmen eğitimi sürecinde nasıl bir mesleki kimlik geliştirdiklerinin ve bu kimliği nasıl geliştirdiklerinin bilinmesi gereklidir. Onların alanlarına ve mesleklerine bakışlarını etkileyen değişkenlerin neler olduğunun belirlenmesi, öğretmen eğitimi sürecinde kimlik oluşumunda yaşadıkları sorunların ortaya konulması, istendik kimlik gelişimi için yapılması gerekenlerin belirlenmesinde oldukça önemlidir. Alanyazındaki araştırmalar incelendiğinde, BT öğretmenleri özelinde öğretmen eğitimi sürecinin öğretmen adaylarının mesleki kimlikleri üzerindeki etkisini ortaya koyan bir 
araştırmaya rastlanmamıştır. Bu gereksinimden hareketle bu çalışmayla, BT öğretmen adaylarının öğretmen eğitimi sürecinde geliştirdikleri mesleki kimlikleri ve öğretmen eğitimi sürecinde bu kimlik yapılarının nasıl biçimlendiği sorusunun yanıtı aranmıştır.

\section{Yöntem}

$\mathrm{Bu}$ başlık altında araştırmanın modeli, çalışma grubu, verilerin toplanması ve verilerin analizi ile ilgili bilgilere yer verilmiştir.

\section{Araştırma Modeli}

$\mathrm{Bu}$ araştırmada nitel araştırma yaklaşımı benimsenmiş olup temel yorumlayıcı desen kullanılarak yapılandırılmıştır. Temel yorumlayıcı desen herhangi bir durumu incelemek ve anlamak üzerine kurgulanan araştırma desenidir. $\mathrm{Bu}$ desende araştırmacılar bireylerin yaşamlarını nasıl yorumladıkları ve dünyalarını nasıl yapılandırdıklarıyla ilgilenmektedirler (Merriam, 2009).

\section{Çalışma Grubu}

Araştırmanın çalışma grubunu, 2016-2017 öğretim yılında Ankara Üniversitesi, Hacettepe Üniversitesi ve Gazi Üniversitesinde öğrenim görmekte olan 36 Bilgisayar ve Öğretim Teknolojileri Eğitimi (BÖTE) Bölümü son sınıf öğrencisi oluşturmaktadır. Görüşme yapılan adayların seçiminde amaçlı örnekleme yönteminden ölçüt örnekleme yöntemi kullanılmıştır. Buna göre Ankara ilinde Türkçe eğitim veren devlet üniversitelerinde öğrenim gören, okul deneyimi dersini başarı ile tamamlamış, öğretmenlik uygulaması dersine devam eden ve mezun durumda olan gönüllü öğretmen adayları araştırmanın çalışma grubunu oluşturmuştur. Bu ölçütlerin belirlenmesinde, özellikle okul deneyimi dersi ile mesleğin okul ortamında nasıl yapıldığını gözlemleme ve deneyimleme olanağı bulan ve bu süreci başarı ile tamamlayan adayların seçilmesine dikkat edilmiştir. Araştırmaya, Ankara Üniversitesinden 13, Hacettepe Üniversitesinden 13, Gazi Üniversitesinden ise 10 son sınıf öğrencisi katılmıştır. Katılımcıların 12'si erkek, 24'ü kadındır.

\section{Veri Toplama Aracı}

Bu araştırmada, BT öğretmen adaylarının öğretmen eğitimi sürecindeki mesleki kimlik yapılarını ve bu yapıları etkileyen değişkenleri belirlemek amacı ile derinlemesine görüşmeler yapılmıştır. Bunun için öncelikle yarı yapılandırılmış görüşme formu oluşturulmuştur. Görüşme formunda BT öğretmen adaylarının alanları ile ilgili ve BT öğretmenlik mesleği ile ilgili düşüncelerini ve inançlarını ortaya çıkartan sorular ile öğretmen eğitimi sürecinin yapılandırdıkları mesleki kimlik üzerindeki etkisini belirlemeye yönelik sorular yer almıştır. Örneğin, BT öğretmeni olarak kendinizi nasıl tanımlıyorsunuz?, Öğretmen eğitimi sürecinizin, geliştirdiğiniz mesleki kimliğiniz üzerindeki etkisini nasıl değerlendiriyorsunuz? gibi sorular yöneltilmiştir. Görüşmeye başlanmadan önce hazırlanan sorular uzman görüşüne sunulmuş ve nitel araştırma ile öğretmen eğitimi konularında araştırmalar yapan iki öğretim üyesi tarafından incelenmiştir. İncelemelerin ardından yapılan düzeltmeler sonucu oluşturulan soruların anlaşılıp anlaşılmadığını belirlemek amacı ile iki BT 
öğretmen adayı ile pilot uygulama yapılmıştır. Bu uygulama sonrasında yapılan düzenlemelerle görüşme formuna son biçimi verilmiştir. Ardından adayların öğrenim gördükleri üniversitelerde görüşmeler gerçekleştirilmiş̧ir. Görüşmeler katılımcıların izni ile ses kaydı alarak gerçekleş̧irilmiş̧ir. Yapılan görüşmelerin uzunluğu 45 dakika ile 117 dakika arasında değişmektedir.

\section{Verilerin Analizi}

Verilerin çözümlenmesi sürecinde öncelikle ses kayıtları yazıya geçirilmiştir. Elde edilen bu veriler tümevarımsal içerik analizi yaklaşımına göre çc̈zümlenmiştir. Veriler, genel bir bakış açısı kazanmak amacıyla birkaç kez okunmuş ve iki seferde kodlanmıştır. İlk seferde veriler açık ve betimsel olarak kodlanmış, ikinci seferde ise kodlar bir araya getirilerek temalar oluşturulmuştur.

Onaylanabilirlik ve inandırıcılık için nitel araştırma dersi almış ve bu konuda araştırmalar yapan, doktorasını tamamlamış bir öğretim elemanı ile birlikte oluşturulan kodlar ve temalar üzerinde çalışılmış ve tek tek yapılan yorum ve öneriler doğrultusunda temalara son biçimi verilmiştir. Araştırma sonuçlarının farklı bağlamlarda uygulanabilirliğini ve aktarılabilirliğini sağlamak amacı ile amaçlı örnekleme yöntemi kullanılmış ve ortaya çıkan temalar yorum katılmadan doğrudan alıntılarla desteklenerek sunulmuştur. Alıntılar verilirken ders ya da öğretim üyelerinin isimleri, gizliliğin sağlanması için üç nokta (...) kullanılarak sunulmuştur. Bulguları sunarken her bir temanın ayrıntılı biçimde sunulmasına özen gösterilmiştir.

\section{Bulgular}

Bu başlık altında araştırmadan elde edilen bulgular alt başlıklar kullanılarak sunulmuştur.

\section{BT Öğretmen Adaylarının BT Alanına ve BT Öğretmenlik Mesleğine Yönelik Düşünceleri ve İnançları}

Yapılan görüşmelerde BT öğretmen adaylarının BT alanını tanımlamalarına yönelik sorular yöneltilmiştir. Adayların bu sorulara verdikleri yanıtlar Tablo 1'de görülmektedir. Tablo 1 incelendiğinde, görüşme yapılan BT öğretmen adaylardan hiçbirinin alanlarını tanımlayamadıkları görülmektedir. Alanı tanımlamaya çalışan adaylar ya çok genel ifadeler kullanarak açık bir tanım yapamamış $(f=22)$ ya da kodlama eğitimi, robotik programlama gibi yeni teknolojilerden ve uygulamalardan söz etmişlerdir $(\mathrm{f}=12)$. Bazı öğretmen adayları ise alanı tanımlamak yerine BT öğretmenlerinin görev ve sorumluluklarına odaklanarak alanlarını anlatmaya çalışmışlardır $(\mathrm{f}=10)$. 
Tablo 1

BT Öğretmen Adaylarına Göre BT Alanı

\begin{tabular}{llc}
\hline Alanın Tanımı & Tanımlamak İçin Verilen Örnekler & f \\
\hline Açık bir tanım yapamama & $\begin{array}{l}\text { Sürekli gelişen teknoloji, bilgi ve iletişim teknolojisi, } \\
\text { her şey, alandaki teknoloji, bilgisayar ve ötesi, problem } \\
\text { çözme, yaratıcı düşünme, hayatın kendisi, çok } \\
\text { kapsamlı, tanımlanması zor vb. }\end{array}$ & \\
\hline $\begin{array}{l}\text { Gündemde olan teknolojiler } \\
\text { ve uygulamalar }\end{array}$ & $\begin{array}{l}\text { Kodlama, robot programlama, Scrach eğitimi, sanal } \\
\text { ortamlar, programlama eğitimi, Ardinio vb. }\end{array}$ & 12 \\
\hline $\begin{array}{l}\text { Tanım yerine görev ve } \\
\text { sorumluluklara odaklanma }\end{array}$ & Teknoloji rehberliği, teknik sorun çözme vb. & 10 \\
\hline
\end{tabular}

Alanın tanımlanmasının ardından adaylara onların gözünden BT öğretmenlerinin kim olduğunu anlamaya yönelik sorular yöneltilmiştir. BT öğretmen adaylarının bu sorulara verdikleri yanıtlar Tablo 2'de yer almaktadır.

Tablo 2

BT Öğretmen Adaylarının Gözünden BT Öğretmenlerinin Kim Olduğu

\begin{tabular}{lc}
\hline Soruyu yanıtlayan öğretmen adayları & f \\
\hline Öğretim programını uygulayan & 32 \\
\hline Teknik destek sağlayan & 32 \\
\hline Öğrencilere ve öğretmenlere teknoloji konusunda rehberlik eden & 28 \\
\hline Okullara yeniliği getiren ve yayan & 25 \\
\hline Öğrencilerin farklı düşünme becerilerini destekleyen & 12 \\
\hline Okullarda öğretim tasarımı yapan & 10 \\
\hline Soruyu yanıtlayamayan öğretmen adayları & 7 \\
\hline
\end{tabular}

Tablo 2 incelendiğinde BT öğretmen adaylarının, BT öğretmenlerini Bilişim Teknolojileri dersi öğretim programına uygun olarak içeriği öğrencilere öğreten (f = 32), okullarda yaşanılan teknik sorunlara destek sağlayan $(f=28)$ ve öğrencilere ve öğretmenlere teknolojinin etkili kullanımı konusunda rehberlik eden $(f=25)$ kişiler olarak tanımladıkları görülmektedir. BT öğretmenlerini okullarda teknik destek sağlayan kiși olarak tanımlayan adayların sayısı oldukça dikkati çekmektedir $(f=28)$. Öte yandan; algoritma, kodlama eğitimi ve robotik programlama gibi konular BT öğretmeni kimdir sorusuna verilen yanıtlarda yine gündeme gelmiş, bazı adaylar BT öğretmenlerini bu yenilikleri getiren ve okullarda etkili kodlama ve robotik eğitimi veren öğretmenler olarak tanımlamışlardır $(\mathrm{f}=12)$.

Tablo 2'de dikkati çeken bir diğer bulgu da görüşme yapılan adaylardan dördünün BT öğretmenlerinin kim olduğunu tanımlayamamaları, hatta bu öğretmenlerin kim olduğunu daha önce hiç düşünmediklerini belirtmeleridir. 
Yapılan görüşmelerde BT öğretmenlerinin kim olduğu ve bu öğretmenlerin sahip olması gereken özelliklerin neler olduğu incelenirken; bazı adayların kendilerini BT öğretmeni olarak hissettikleri, bazılarının ise farklı nedenlerden dolayı kendilerini BT öğretmeni olarak hissedemedikleri belirlenmiştir. Ortaya çıkan bu farklı durum ve nedenleri Tablo 3’te görülmektedir.

Tablo 3

BT Öğretmen Adaylarının Kendilerini BT Öğretmeni Olarak Hissetme/Hissedememe Nedenleri

\begin{tabular}{lr}
\hline & f \\
\hline Kendilerini BT öğretmeni olarak hissettiğini belirten adayların özellikleri & $\mathbf{1 1}$ \\
\hline Bölümü sevme ve isteyerek tercih etme & 8 \\
\hline Öğretmenlik mesleğini çok isteme & 7 \\
\hline Alan bilgisi boyutunda kendini yeterli hissetme & 5 \\
\hline Öğretmen eğitimi boyunca kendini geliştirme & 5 \\
\hline Kendilerini BT öğretmeni olarak göremediğini belirten adayların özellikleri & $\mathbf{2 5}$ \\
\hline Alan bilgisi boyutunda kendini yetersiz hissetme & 23 \\
\hline Bölüme isteyerek gelmeme & 19 \\
\hline Alanı sevmeme/ilgi duymama & 12 \\
\hline Yeterli öğretmenlik uygulaması deneyimine sahip olmama & 10 \\
\hline Öğretmen olmayı hiç istememe & 6 \\
\hline
\end{tabular}

Tablo 3 incelendiğinde, kendilerini BT öğretmeni olarak gördüklerini belirten adaylar; bölüme ne olacaklarını bilerek ve isteyerek geldiklerini ( $\mathrm{f}=8$ ), BT öğretmenliğinden önce öğretmen olmayı çok istediklerini ( $f=7)$, alanda kendilerini yeterli hissettiklerini $(f=5)$ ve öğretmen eğitimi sürecinde de kendilerini bu anlamda geliştirmek için çabaladıklarını $(\mathrm{f}=5)$ belirtmişlerdir. Bu konuda iki BT öğretmen adayı şöyle söylemiştir:

"Bölüme öğretmen olmayı çok isteyerek geldim. Meslek lisesinde de alanımı çok sevmiştim. Bu yüzden bu bölüm benim hayalim oldu” (K9).

"Kendimi çok iyi bir BT öğretmeni olarak görüyorum. Çünkü hem istediğim mesleği yapacağım hem de 4 yıl boyunca kendimi geliştirmek için yaptıklarımın karşılığını alacağım. Birçok eğitime, seminere, kurslara, etkinliklere katılıdım” (K25).

Öte yandan, adayların yarısından fazlası farklı nedenlerle kendilerini BT öğretmeni olarak göremediklerini belirtmişlerdir. Kendilerini BT öğretmeni olarak görememelerinin altında en fazla alan bilgisi boyutunda kendilerini yetersiz hissetmeleri $(\mathrm{f}=23)$, bölüme isteyerek gelmemeleri ( $\mathrm{f}=19)$ ve alana ilgi duymamaları $(f=12)$ yer almaktadır. Burada en dikkat çeken nokta eğitim fakültesine hiç öğretmen olmak istemeyen adayların da gelmiş olmasıdır $(f=6)$. Konu ile ilgili olarak üç BT öğretmen adayı şöyle söylemiştir: 
"Bence aynı konuyu farklı sınıflara defalarca anlatmak beni çok fazla sıkar, aynı örnekler, aynı ders... Tatmin etmeyecek beni... Benim istediğim şey öğretmenlik değil, ama maalesef öğretmen olacağım" (K3).

“Öğretmenliği seviyorum ama alanımı sevmiyorum, istemiyorum. Bu yüzden iyi bir BT öğretmeni olabileceğimi düşünmüyorum” (K26).

"Sadece ailem istediği için bu bölümdeyim. Ne kadar bu işi yapmak istiyorum siz düşünün" (K19).

\section{Öğretmen Eğitimi Programının BT Öğretmen Adaylarının Mesleki Kimlikleri Üzerindeki Etkisi}

Araştırmadan elde edilen bulgular, öğretmen eğitim programlarının BT öğretmenlerinin mesleki kimliklerini etkileyebildiğini ortaya koymuştur. Özellikle alan bilgisi ve meslek bilgisi derslerinin içeriği, işleniş biçimi, öğretim üyeleri ile kurulan iletişim-etkileşim ve sağlanan kurumsal destek boyutunun mesleki kimliklerin biçimlenmesini etkilediği belirlenmiştir.

BT öğretmen adaylarının öğretmen eğitimi sürecinde aldıkları alan bilgisi derslerinin geliştirdikleri mesleki kimlik üzerindeki etkisi. Adaylara öğretim programlarındaki alan bilgisi derslerinin neler olduğu sorulduğunda adayların programlama dilleri, web tasarımı, donanım gibi teknik bilgi gerektiren dersleri alan bilgisi olarak tanımladıkları belirlenmiştir. BT öğretmen adaylarına göre, öğretmenlik mesleğini yürütmek istesin ya da istemesin adayların hem kariyer planlarında hem de oluşturdukları mesleki kimlik yapılarında aldıkları alan bilgisi eğitiminin önemi oldukça fazladır. Onlara göre alanını iyi bir biçimde tanımak, anlamlandırmak, öğretilecek içeriğin farkında olmak, mesleki yaşantılarında kullanılacak teknik bilgi ve becerileri kazanmak ve mesleki gelişimlerini sağlam bir biçimde sürdürmek, alınan nitelikli alan bilgisi eğitimi ile olanaklı görülmektedir. Bu nedenle oluşturdukları mesleki kimlik üzerinde alan derslerinin olumlu ve olumsuz etkilerini oldukça sık tartışmışlardır. Tablo 4'te alan bilgisi derslerinin BT öğretmenlerinin mesleki kimliklerini etkilediği boyutlar yer almaktadır.

Tablo 4

Alan Bilgisi Derslerinin BT Öğretmen Adaylarının Mesleki Kimlikleri Üzerindeki Etkisi

\begin{tabular}{lr}
\hline Etkileme Boyutları & f \\
\hline Yeterli teknik bilgi ve beceri kazandırma & 32 \\
\hline İçerik bilgisi ve uygulama yeterliği & 29 \\
\hline Öğretim üyesinin alan ve mesleki yeterliği & 25 \\
\hline Öğretim üyesinin derse hazırlığı & 12 \\
\hline Öğretim üyesi ile kurulan iletişim ve etkileşim & 22 \\
\hline Öğretim üyesinin dersine/mesleğine verdiği önem & 10 \\
\hline
\end{tabular}


Tablo 4 incelendiğine, alan bilgisi derslerinin BT öğretmen adaylarının mesleki kimliklerini üç boyutta etkilediği belirlenmiştir. Bu boyutlar, yeterli teknik bilgi ve beceri kazandırma, öğretim üyesi ile kurulan iletişim ve etkileşim, öğretim üyesinin dersine/mesleğine verdiği önem biçimindedir.

Yeterli teknik bilgi ve beceri kazandırma. BT öğretmen adaylarının öğretmen eğitimi sürecinden en büyük istekleri, alanda yeterli teknik bilgi ve beceriyi kazanarak mezun olmaktır. Bu nedenle özellikle alanına hakim, dersin en başından planlı hareket eden ve içeriği etkili biçimde sunan öğretim üyelerinden aldıkları dersler onlara çok şey kazandırmıştır. Adaylara göre etkili olduğunu düşündükleri derslerde öğretim üyeleri farklı uygulamalar ile örnekler sunarak ve bunlar üzerinde tartışmalar yaparak yeni teknolojilerle birlikte ürüne dönük materyaller ortaya konulmasını sağlayarak adayların kendilerini iyi yetişmiş ve yeterli hissetmelerini sağlamıştır. Konu ile ilgili olarak üç BT öğretmen adayı şöyle demiştir:

Hoca alanına çok hakim, bu çok belli oluyor. Ve ondan ders alırken her hafta ne işleyeceğimizi, neleri göreceğimizi gördük. "Ben de planlı olmalıyım" dedim. Teknik olarak da farklı uygulamaları ve örnekleri getirdi, gerçekten hoca bilgisini aktardı ve çok şey öğrendim. (K27)

"Bu ders bizim ilk defa gerçek sınıf ortamını gördügüümüz ders oldu. İyi örnekleri, kötü örnekleri izledik, tartıştık. Lisans eğitiminde bana BT öğretmenliği anlamında en fazla katkı sağlayan ders oldu. Beni hayata hazırladı” (K35).

... hocasından ders aldığım için o kadar şanslıyım ki. Gümbür gümbür geliyor, kendini çok iyi geliştiriyor ve konuyu bize en iyi şekilde öğretmek için araştırıyor, uğraşıyor, ne varsa yeni buluyor ve onu getiriyor. Bölümde örnek aldığım ve herkes keşke onun gibi olsun dediğim bir hoca. (K5)

Öte yandan, o alanda ders verebilecek öğretim üyesinin olmaması ya da var olan öğretim üyesinin o alanda yetersiz olması, bu öğretim üyesinin içeriği etkili ve verimli bir biçimde sunamaması, bazen ders yerine kendi yaşam hikayelerini anlatması, derslerini teknik anlamda yeteneği olan öğrencilere anlattırması ya da içeriği öğrencilere paylaştırarak dönem boyunca onlara sundurması gibi sorunlar, BT öğretmen adayları tarafından sıkça dile getirilmiştir.

Bazı adaylar ise bilgisayar başında uygulama yapılması gereken derslerin bile kitaptan birebir işlenerek kağıt üzerinde uygulama yapılması, farklı örnek uygulama yapılmadan içeriğin çok hızlı atlanması, anlatımın çok üst düzey kalması ya da hiç bir şey anlatılmaması gibi çeşitli nedenler ile alan derslerinden istenilen verimi alamadıklarını vurgulamışlardır. Yaşanılan tüm bu sorunlar adayların geliştirmiş olduğu benlik algısı, öz-yeterlik, geleceğe bakış ve mesleki bağlılıklarına yani başka bir deyişle mesleki kimliklerine zarar verebildiğini göstermektedir. Konu ile ilgili olarak üç BT öğretmen adayı şöyle demiştir: 
“... dersinin en iyi hocasısın ama anlatamıyorsun. Uyumamak için kendimi zor tutuyorum. Bana ne senin çocuklarından, kendi hayatından, aldığın arabadan... Böyle aldığım dersler yüzünden bu mesleğin hakkını vereceğimi düşünmüyorum” (K2).

Hiçbir şey anlatmadı, o kadar pişmanım ki o dersi bu hocadan aldığıma. O kadar boş geçti ki. İçerik yok, objektiflik yok, tutarlı değil. Bir öğretmen hiçbir şekilde böyle olmamalı. İleride nasıl olmamam gerektiğini öğrendim sadece. Maalesef o alanda kendimi çok boş hissediyorum. (K15)

“Biz BT öğretmeni olacağız, yeni teknolojileri bilen, kullanan öğretmen. Hâlâ neden tepegözü konuşuyoruz, kağıtla materyal yapıyoruz, bunu anlamıyorum. Bu ders yüzünden kendimi okullarda yeni teknolojilerin kullanımını sağlayacak öğretmen değilmişiz gibi hissediyorum” (K30).

Öğretim üyesi ile kurulan iletişim ve etkileşim. BT öğretmen adaylarının öğretim üyeleri ile kurdukları iletişim ve etkileşim, sunulan içeriğin öğrenilmesi kadar onların geliştirdikleri mesleki kimlik yapılarını da etkilemiştir. Çünkü adaylar, öğrenme sürecinde öğretim üyeleri ile çekinmeden, olumsuz eleştirileceğini düşünmeden düşüncelerini ve sorunlarını paylaşabilmek; onlardan gelen geri bildirimlerle ve yönlendirmelerle gelişimlerini desteklemek istemişlerdir. Bu noktada, rahat iletişim kurabildikleri, sorularına yanıt alabileceklerini düşündükleri, kendilerine zaman ayırarak gerekli bilgi ve yönlendirmeyi sağlayan öğretim üyelerinden çok etkilenmişlerdir. Bu derslerde öğretim üyesi ile kurulan iyi iletişim ve etkileşim bir yandan öğrencilerin kendilerini değerli hissetmelerini sağlarken, diğer yandan onların derse olan ilgisini arttırmıştır. Konu ile ilgili bir BT öğretmen adayı şöyle demiştir:

"Hocamız çok sevecen biri bence ve yardımsever. Bizi dinliyor, zaman ayırıyor, bazen tek tek sorunlarımızı dinlediği oluyor. Ve gelişmemiz için çaba harcıyor. Bu beni değerli hissettiriyor. Bizimle iyi iletişim kuran ve ilgilenen hocaları da derslerini de çok seviyorum” (K23).

Rahat iletişim ve etkileşim kurabildikleri derslerin aksine BT öğretmen adayları bazı alan derslerinde öğretim üyesinin mesafeli ya da soğuk durması nedeni ile iletişim kuramadıklarını, kendilerini ifade edemediklerini, sorularına yanıt alamadıklarını, bu nedenle özellikle ürün geliştirme süreçlerinde yalnız kaldıklarını belirtmişledir. Bazı adaylar ise iletişim kurduklarında ise aldıkları geri bildirimlerin tutarlı olmadığını ya da olumsuz geri bildirimler nedeni ile bir daha iletişim kurup sorunlarını çözme konusunda isteklerinin kalmadığını vurgulamışlardır. Yaşanılan bu iletişim sorunları adayları değersiz, önemsiz ve yalnız hissettirmiştir. Konu ile ilgili olarak iki BT öğretmen adayı şöyle demiştir:

"Bir kere hoca soğuk... İletişim sorunumuz var, bizi anlamıyor ya da anlamak istemiyor, çok sert, yüzümüze bakmıyor, ses tonu bile bana geçmiyor. Onu gördükçe bölümden soğuyorum” (K24). 
Bize derste "bir problem bulun, gelin" dedi, ama sonrasında seçtiğimiz problemle ilgili hiç dönüt vermedi, biz doğru mu yaptık, yanlış mı yaptık bilemeden dönem bitti. Zaten biz de sormadık ya azarlayacaktı ya da yine çok farklı dönütler verecekti. Hiçbir şey öğrenemeden dönem bitti. (K11)

Öğretim üyesinin dersine/mesleğine bakışı ve verdiği önem. BT öğretmen adaylarına göre öğretim üyesinin alana ve mesleğe bakışı, dersin işleniş biçiminden derslerde yaptıkları yönlendirmelere kadar pek çok boyuta yansımıştır. Alanları ile birlikte öğretmenlik mesleğinin değerli olduğunu düşünen öğretim üyeleri derslerinde, bunun vurgusunu yapmakta ve adayları meslek anlamında daha iyi gelişmeleri için yönlendirmektedir. Ancak yapılan görüşmelerde adaylardan bazıları, alan dersi veren bazı öğretim üyelerinin öğretmenlik mesleğine karşı olumsuz bir bakış açısına sahip olduğunu belirtmişlerdir. Bu öğretim üyeleri, adayları öğretim tasarımcısı ya da yazılımcı olarak özel sektöre yönlendirmekte, zaman zaman öğretmenlik mesleğine yönelik olumsuz yorumlar yapmakta, hatta öğretmen olarak atanamama durumunu alay konusu durumuna getirmektedir. Özellikle öğretmen olmayı istediği için eğitim fakültesine gelen adaylar, bu alan derslerinde benlik algısı ve görev algısı boyutlarında karmaşa yaşamaya başlamışlardır. Bu durum adayların meslek/bölüm ile ilgili algısını değiştirmiş, gelecekte kim olacaklarına iliş̧kin yaşadıkları karmaşaları arttırmıştır. Konu ile ilgili olarak üç BT öğretmen adayı şöyle demiştir:

Örneğin ... hocasına ve dersine çok saygımız var, o bir şeyi yap deyince yapıyoruz, dersine daha fazla özen gösteriyoruz. Çünkü hocanın kendi dersine saygısı var, bize bunu hissettiriyor. Bu hoca bana dersinde alanımın değerli olduğunu ve benim buna değer vermem gerektiğini hissettirdi. (K6)

"Ben ... hocasının bizi öğretmen olarak yetiştirdiğine inanmıyorum. Derste verdiği örnekler hep özel sektör ile ilgili. Oradaki başarıları ve başarısızlıklarıyla ilgili. Maalesef bu ders öğretmen kimliğimden çok sektör kimliğimi geliştirdi” (K35).

Öğretmenlik yapmak isteyenler bu bölümü bıraksın! diyen hocalarımız var

bizim. "Öğretmenlik bitti buraya neden geliyorsunuz" diyorlar. Düşünebiliyor musunuz yaşadığımız şoku. Ben öğretmen olmak istiyorum, nereye gidecektim. Öğretmen olmak isteyen birinin bunları duymasının yarattığı yıkımı tahmin edemezsiniz ... bizimle atanamayacaksınız zaten diye dalga bile geçiliyor. (K11)

Alan derslerinin işleniş sürecinde yaşanılan bu sorunlar, BT öğretmen adaylarının kendilerini alanda yetersiz hissetmelerine, özgüven eksikliği yaşamalarına ve oluşan bu yetersizlik hissi ile mesleği sürdürme konusunda kararsızlık yaşamalarına neden olmuştur. İki BT öğretmen adayı yaşadığı pişmanlı̆̆ı, yetersizlik algısını ve meslek seçimi ile ilgili pişmanlığını şöyle dile getirmiştir:

"Sayılı bir üniversitedeyim. Hem hocaların alana bakışı hem de derslerin bu biçimde işlenmesi acaba başka bir bölümde mi okusaydım, başka bir meslek mi 
seçseydim, gerçekten atanamayacak mıyım, geleceği olmayan bir bölümde miyim gibi olumsuzlukları getiriyor, korkularım artıyor” (K8).

"Ne alana hakimim diyebiliyorum ne de mesleğe. Zaten atanınca ne olacağı kısmı karanlık. Öğretmenlik istiyorum ama yapabilecek miyim, iyi bir öğretmen olabilecek miyim bilmiyorum” (K35).

BT öğretmen adaylarının öğretmen eğitimi sürecinde aldıkları meslek bilgisi derslerinin geliştirdikleri mesleki kimlik üzerindeki etkisi. BT öğretmen adaylarına göre, iyi bir BT öğretmeni olabilmek için sağlam bir alan eğitimi ile birlikte içeriğin etkili sunulduğu, farklı yöntem ve tekniklerin kullanıldığg, çok çeşitli örneklerle ve örnek olaylarla zenginleştirilen iyi bir mesleki eğitim almak gerekmektedir. Çünkü BT öğretmeni kimdir, öğreteceğimiz hedef kitlenin özellikleri nelerdir, içeriğgi etkili bir biçimde nasıl sunabiliriz, öğretim sürecini nasıl zenginleştirebiliriz, öğrenmeleri nasıl değerlendirebiliriz? gibi sorulara en etkili yanıt, iyi bir öğretmen eğitimi ile olanaklıdır. Yapılan görüşmelerde BT öğretmen adaylarının eğitim bilimine giriş, eğitim psikolojisi, sınıf yönetimi, öğretim tasarımı gibi dersleri meslek bilgisi dersleri olarak ele aldıkları belirlenmiştir. Özellikle öğretim tasarımı ve özel öğretim yöntemleri 2 dersleri, alan dersleri olmasına karşın BT öğretmen adayları tarafından meslek bilgisi dersleri olarak ele alınmıştır. Tablo 5'te meslek bilgisi derslerinin BT öğretmen adaylarının mesleki kimliklerini etkilediği boyutlar yer almaktadır.

Tablo 5

Meslek Bilgisi Derslerinin BT Öğretmen Adaylarının Mesleki Kimlikleri Üzerindeki Etkisi

\begin{tabular}{lr}
\hline Etkileme boyutları & f \\
\hline Nitelikli meslek bilgisi ve becerisi kazandırma & 25 \\
\hline İcerik bilgisi ve uygulama yeterliği & 22 \\
\hline Alana hâkim öğretim üyesinin olması & 13 \\
\hline Öğretim üyesinin derse hazırlığı & 9 \\
\hline Derslerde ilköğretim okullarında gözlem/uygulama yapma olană̆ı bulma & 15 \\
\hline Meslek bilgisi ile alan gereksinimlerini birleştirilebilme & 10 \\
\hline Öğretim üyesinin rol model olması & 9 \\
\hline Öğretim üyesi ile kurulan iletişim ve etkileşim & 8 \\
\hline
\end{tabular}

Tablo 5 incelendiğinde BT öğretmen adayları, derslerde nitelikli meslek bilgisi kazanabilmelerinin $(f=25)$ mesleki kimliklerini etkilediğini belirtmişlerdir. Tıpkı alan bilgisi derslerinde olduğu gibi meslek bilgisi derslerinde de adaylar en fazla sunulan içerik bilgisinin yetersizliği $(f=22)$, öğretim üyesinin alana hakim olmadığına ilişkin algıları $(\mathrm{f}=13)$ ve öğretim üyelerinin derse hazırlıklı gelmemesi ( $\mathrm{f}$ =9) nedenleri ile kendilerinin iyi yetişmediğini vurgulamışlardır. İki BT öğretmen adayı konu ile ilgili şöyle söylemişlerdir: 
Bizim stajda en fazla sorun yaşadığımız ders .... dersi oldu. Sınıfı nasıl yöneteceğiz, iletişim kuracağız bunu hâlâ bilmiyoruz. Derste pek bir şey öğrenemedik. Hoca konuyu böldü geçti, bize anlattırdı, kendisi bir şey anlatmadı. Bu yüzden beni sınıfı yönetememek çok korkutuyor. (K23)

"Bence bu dersin hocası daha anlatacağı içeriği bilmiyordu. Yıllar önce bir sunum hazırlamış her sene aynı sunumu hiçbir güncelleme yapmadan kullanıyor. Sunumu bize okuyarak nasıl iyi bir öğretmen olmamızı destekleyebilir ki..." (K9).

Alan derslerinden farklı olarak BT öğretmen adayları meslek bilgisi derslerini deneyim elde etmek amacı ile ilköğretim okullarında gözlem ve uygulama yapma olanağı sunması $(f=15)$, meslek bilgisi ile alan gereksinimlerini birleştirebilmeleri ( $\mathrm{f}$ $=10)$ ve öğretim üyesinin kendilerine rol model olması $(f=9)$ boyutlarının mesleki kimliklerini etkilediğini tartışmışlardır.

İköğretim okullarında gözlem ve uygulama yapma olană̆ı sunulması. BT öğretmen adayları hem alan bilgisi hem de meslek bilgisi derslerinde kazandıklarını ilköğretim okullarındaki sınıf ortamında nasıl uygulamaya dökeceklerini, süreçte ne gibi sorunlar yaşayacaklarını ve bu sorunları nasıl çözüme ulaştırabileceklerini görmek ve deneyimlemek istemektedirler. Bunun için bazı adaylar bazı meslek bilgisi derslerinde sınıf ortamını deneyimleyebilecekleri uygulamalar yaptıklarını, gerçek sınıf videolarını izlediklerini ve/veya örnek olaylarla içeriğin desteklendiğini belirtmişlerdir. Ancak pek çoğu için bu destek yeterli değildir ve eksikliği kendilerini yetersiz hissetmelerine neden olmaktadır. Bir BT öğretmen adayı konu ile ilgili şöyle demiştir:

Staja gidene kadar başka hiçbir derste gerçek sınıf videoları izlemedik, BT öğretmenlerinin yaşadıkları sorunları bu kadar net bir biçimde görmedik. $\mathrm{Bu}$ dersi videolarla izlediğimiz için çok şanslıyız. Keşke diğer meslek derslerinde de gerçek sınıf ortamını görme imkanımız olsaydı. Mesleğe bakışımız daha erken netleşebilirdi. (K30)

Öte yandan, BT öğretmen adaylarına göre okul deneyimi ve öğretmenlik uygulaması dersleri, adayları gerçek yaşama hazırlama ve onların gelecek planlarına yön verme konusunda oldukça önemlidir. Bazı adaylar öğretmenlik deneyimi ile mesleğe ilgi duymaya başlamış ve gelecek planlarını BT öğretmeni olma yolunda yeniden düzenlerken, bazıları bu süreçte mesleği yapabileceğine olan inancını kaybetmiştir. İki BT öğretmen adayı öğretmenlik uygulaması derslerinin mesleği sürdürme boyutundaki etkisini şöyle dile getirmiştir:

"Son sınıf oldum ama hâlâ acemiliğimi üstümden atamadım, ne yapmam gerektiğini bilmiyorum. Verilen stajın zamanı da yeterli değildi ve son sınıf gerçek ortamı görmek için çok geç. Sınıfta uygulama yapmak için çok geç” (K29).

"Daha önce öğretmenliği o kadar düşünmüyordum, ama okul deneyimi ile birlikte fikirlerim tamamen değişti, çok keyif aldım ve ben bu işi yapabilirim dedim. Şimdi öğretmen olmak istiyorum” (K20). 
Okul deneyimi ve öğretmenlik uygulaması derslerinin adayların mesleki kimliklerinin üzerindeki etkisi yalnızca gelecek planları boyutunda olmamıştır. Yapılan görüşmelerde üniversitelerindeki akademik danışmanların, uygulama okulundaki rehber öğretmenlerin ve öğretmen adaylarının uygulama okullarında deneyimledikleri kurum kültürünün mesleki kimlikleri üzerindeki etkisi oldukça tartışılmıştır. Alanda iyi ve yardım etmeye istekli bir BT öğretmeni rehberliğinde gelişmek, ilköğretim okullarında farklı öğretimsel süreçleri gözlemlemek ve üniversitelerdeki akademik danışmanlardan yeterli destek ve yönlendirmeyi almak, adayların mesleği daha iyi anlamlandırmalarına 1şık tutmuştur. Ancak tersine, atamasının bile yapılmayacağı liselerde okul deneyimine gitmek, kendilerine rol model olamayan isteksiz bir rehber öğretmenle çalışmak ya da üniversitedeki akademik danışmanlardan yeterli desteği alamamak, onların mesleki gelişimlerini olumsuz etkilemiş ve meslekten uzaklaştırmıştır. Konu ile ilgili olarak üç BT öğretmen adayı şöyle demiştir:

"Stajdaki hoca çok farklıydı, bazen sınıfı tamamen bize bıraktı gitti, bazen hiç ders anlatmadı. Onların bu tavrı benim hem derse hem de geleceğimize bakışımı farklılaştırdı. Stajdan sonra öğretmenlikten soğudum resmen. Halbuki ne kadar çok istiyordum” (K30).

"Staj hocasının duruşu, dersine hazırlanışı ve mesleğine verdiği değer bizim de derse ve mesleğe bakışımızı çok etkiliyor. Ben iki farklı ucu da deneyimledim. İlk dönem ben bu işi asla yapamam derken şimdi umarım atanırım diyorum” (K19).

"Üniversitedeki hocam beni izlemeye bile gelmedi, ders planlarımı bile incelemedi. Öylece sadece gittim geldim. Nasıl olduğumu, iyi miyim, nerelerde eksiğim hâlâ bilmiyorum" (K6).

Meslek bilgisi ile alan gereksinimlerini birleştirilebilme. BT öğretmen adayları meslek bilgisi derslerini alırken bu derslerin alanları (BT alanı) ile daha fazla bağlantı kurularak verilmesini istemektedirler. Bu bağlantının iyi kurulması ile BT öğretmeni olarak görev ve sorumluluklarını, özlük haklarını daha iyi kavrayacak, laboratuvar ortamında işledikleri derste kazandıkları mesleki bilgilerini nasıl kullanabileceklerini tartışabileceklerdir. Ne yazık ki pek çok aday, aldıkları meslek derslerini eleştirmiş ve iyi bir BT öğretmeni olarak yeterli desteği meslek derslerinde alamadıklarını dile getirmişlerdir. Bu ikisi arasındaki eksiklik nedeni ile BT öğretmeni kendisini yeterli hissedememektedir. Bir BT öğretmen adayı konu ile ilgili şöyle demiştir:

Bize meslek bilgisi verdiler ama bu öğrendiklerimizi BT dersinde nasıl kullanacağımızı öğretmediler. Alan ile ilgili kısmı hep havada kaldı. Hâlâ bu içeriği nasıl öğreteceğimi bilmiyorum. Bu yüzden kendimi yeterli hissetmiyorum. İyi bir BT öğretmeni olmam gerekiyorsa alana özgü meslek bilgisi elde etmem gerekirdi. (K10)

Öğretim üyesinin rol model olmast. BT öğretmen adayları meslek bilgisi derslerinde bir yandan kuramsal bilgiyi elde ederken öte yandan öğretim üyelerini gözlemleyerek bazılarını kendilerine rol model almışlardır. $\mathrm{Bu}$ süreçte öğretim 
üyelerinin alan bilgisi, mesleki gelişim çabası, öğretim becerisi ve öğretim sürecini etkili yönetmesi ile birlikte mesleki duruşu, sağladığı destek ve kurduğu iletişim ve etkileşim de göz önünde bulundurulmuştur. Bir BT öğretmen adayı konu ile ilgili şöyle demiştir:

"Bayılıyorum ... hocanın dersine. Duruşuyla, konuşmasıyla, öğretimi ile bize verdiği değer ile işte eğitim fakültesindeyim diyorsunuz" (K3).

Ancak BT öğretmen adayları, bazı meslek bilgisi derslerini veren öğretim üyelerinin sunduğu içeriğe uygun davranışları göstermemeleri nedeni ile yaşadıkları sorunları dile getirmişlerdir. Örneğin, bazı meslek derslerinde iyi bir sınıf yönetiminin nasıl olacağı, farklı yöntem ve tekniklerin derslerde nasıl uygulanacağı ya da öğrencilerle iletişimin nasıl kurulacağı kuramsal olarak anlatılmasına karşın, öğretim üyelerinin kendi derslerinde öğretmen adaylarına sundukları kuramsal bilgilerle tutarlı uygulamalar yapmadıkları belirtilmiş̧ir. Bir BT öğretmen adayı konu ile ilgili şöyle demiştir:

"Dersi anlatırken sınıf kalabalık olmayacak, karanlık olmayacak, slayta bağlı kalınmayacak, öğrencilerle iletişim kurulacak dedi ama hoca bu dediklerinin hiçbirini kendi dersinde uygulamadı. Örnek almayı bırakın, bu hocanın yaptıklarını yapma diye kodladım. Sözde bu derste iyi öğretmen olmayı öğreniyoruz” (K22).

Sağlanan kurumsal desteğin BT öğretmen adaylarının mesleki kimlikleri üzerindeki etkisi. Görüşmelerde öğretmen eğitimi sürecinde üniversitelerin BT öğretmen adaylarına sağladığı pedagojik, sosyal ve teknik desteğin, adayların nitelikli biçimde gelişmesinde etkisinin üzerindeki etkisi olduğu belirlenmiştir. Bu bağlamda BT öğretmen adayları özellikle BÖTE bölümlerine sağlanan bilgisayar laboratuvarlarını ya da BT sınıflarını, teknik altyapıyı, yazılım ve donanım desteğini eleştirmişlerdir. Öte yandan üniversitelerde adayların hem alan hem de mesleki boyutta gelişimi için düzenlenen eğitimler, konferanslar ve çalıştayların önemi vurgulanmıştır. Üniversitelerde yapılan bu ve benzeri etkinliklere katıldıkça adaylar kendilerini daha güçlü, nitelikli ve yeterli hissettiklerini belirtmişler, daha fazlası için öneriler getirmişlerdir. İki BT öğretmen adayı konu ile ilgili şöyle demiştir:

"Hâlâ sınırlı robotla bir şeyler öğrenmeye çalışıyoruz, internet sorunlu sınıflarda ders yapmaya çalışıyoruz, yazılımlarımız da eksik. BT alan öğretmeniyiz ama hâlâ üniversitede bu teknik sorunları yaşıyoruz" (K26).

"Üniversitenin düzenlediği seminerler çok faydalı oldu, farklı uzmanlar, psikologlar, öğretmenler geldi ve konuştuk, tartıştk. Bizim kendimizi geliştirmemizi, iyi hissetmemizi sağladılar" (K34).

\section{Mesleki Kimlik Gelişimi İçin Bireysel Çaba ve Özeleştiri}

BT öğretmen adaylarından bazılarına göre, öğretmen eğitimi sürecinde kendilerini alanlarında ve mesleklerinde yeterli hissedememelerinin tek sorumlusu öğretmen eğitim programları değildir. Bazı adaylar kendilerini de eleştirmiş, sürecin en başından beri süregelen eksikliklerini ve yanlışlarını dile getirmişlerdir. Dördüncü 
sınıfa kadar alanlarına/mesleklerine ilgilerinin olmaması nedeni ile kendilerini mesleki boyutta ve alan boyutunda geliştirmek için yeterince çaba harcamamaları (f $=15)$, hazırcılıkları $(f=11)$, tembellikleri $(f=10)$, her şeyin derste öğrenileceğini düşünmeleri ( $f=10)$, sürekli hocaları eleştirmeleri $(f=9)$ ve hiçbir şey yapmadan sürekli şikayet etmeleri $(f=5)$, kendilerinden kaynaklanan en temel sorunlar arasında dile getirilmiştir. Ne yazık ki bu adaylar pişman olsalar da artık pişmanlık için çok geç olduğunun da farkında olup halen başka yollar bulmak için çaba göstermemektedirler. Üç BT öğretmen adayı konu ile ilgili şöyle demiştir:

"Kendim yanlış bölüme geldim ve dönüş yok. Belki daha erken bir şeyler yapabilirdim ama yapmadım” (K1).

"Herşeyi hazır hocalardan beklemek yerine kendimi geliştirmek için daha çok şey yapmalıydım. Hiç bir şey yapmadım. Suçu biraz da kendimizde aramamız lazım. Hata tabii ki bende de var” (K27).

"Ben hep dersi geçeyim diye baktım, kolay geçiliyorsa hiç sorgulamadım, son sınıfa geldiğimizde dank etti. Ne kadar eksik ve yetersiz olduğumuzu o zaman anladık. Ama artık çok geç” (K11).

\section{Tartışma, Sonuç ve Öneriler}

BT öğretmen adaylarının öğretmen eğitimi sürecinde geliştirdikleri mesleki kimliklerini ve öğretmen eğitimi sürecinin bu kimlik yapılarını nasıl etkilediğini ortaya koymak amacı ile yapılan araştırmada, öğretmen adaylarının yarısından fazlasının öğretmen eğitimi sürecinde istendik bir mesleki kimlik geliştiremediği, pek çoğunun BT öğretmenlerinin kim oldukları ve okullarda ne iş yaptıkları ile ilgili net bir fikre sahip olmadıkları belirlenmiştir. Bu adaylar arasında, eğitim aldıkları alanı açık bir biçimde tanımlayamayan, BT öğretmenlerinin görev ve sorumluluklarının neler olduğunu daha önce hiç düşünmediklerini dile getiren, hatta hiçbir biçimde öğretmen olmak istemediklerini belirten adayların olması oldukça şaşırtıcıdır. Araştırmadan elde edilen sonuçlara göre, BT öğretmen adaylarının kendilerini BT öğretmeni olarak hissedebilmelerinin altında, öncelikle meslek/alan ile ilgili sahip oldukları inançların, mesleğe/alana karşı duydukları ilginin, bölümü tercih nedenlerinin, öğretmenlik mesleğini sürdürme isteğinin ve bireysel gelişim çabalarının etkisinin olduğu görülmektedir. Meslek ve alan ile ilgili yeterli bilgiye sahip olmadan, istemeyerek tercih yapan, mezun olduklarında ne olacakların tam olarak bilmeyen ya da öğretmenlik dışında farklı mesleklere yönelebilme fikri ile bölümü tercih eden adayların mezun olurken de aynı isteksizlik ve belirsizliklere sahip olabileceği bir gerçektir. Belirsizliklerle ve isteksiz biçimde gelen bu adaylar mezun olduktan sonra mesleklerini ya hiç yapmamakta ya da yaklaşık ilk beş yılda öğretmenlik mesleğini terk etmektedir (Ingersoll ve Smith, 2003; Lindqvist, Nordänger ve Carlsson, 2014; Stokking, Leenders, De Jong ve Van Tartwijk, 2003). Adayların mutlu ve güdülenmiş biçimde, öz-yeterliklerine inanarak, mesleklerine bağlı ve değerinin farkında olarak mesleklerini sürdürebilmeleri için daha öğretmen eğitimi sürecine girmeden önce kendilerini tanımaları, gereksinimlerini, isteklerini ve 
beklentilerini açık bir biçimde belirlemeleri ve tercihlerini bu doğrultuda yapmaları gerekmektedir. Ancak ne yazık ki pek çok BT öğretmeni genel lise, anadolu lisesi ve meslek lisesi gibi farklı liselerden mezun oldukları için istemedikleri halde BÖTE bölümünü seçmek zorunda kalmakta ya da farklı sektörlere yönelebilme hayali ile bölümü tercih etmektedir (Erdoğan, 2008; Karataş, 2010; Önal, 2018). Öğretmenlerin mesleki kimlik gelişimini temelden etkileyen bu sorunun çözümü için daha meslek seçimi sürecinde tercih aşamasında birtakım önlemler alınabilir. Bunun için öğretmen eğitimine başlamadan önce farklı değerlendirme süreçleri işe koşularak gerçekten öğretmenlik mesleğini yapmak isteyen ve BT alanına ilgisi ve yeteneği olan adayların bölümü tercih etmesi ve yerleşmesine yönelik düzenlemeler yapılabilir. Böylece gerçekten bu mesleği yapmayı isteyen, meslekte ve alanda belli yeterliğe sahip olan adayların yetişmesi sağlanabilir.

Araştırmada elde edilen bulgulara göre, BT öğretmen adaylarının sahip olduğu bireysel özellikleri ve deneyimleri dışında öğretmen eğitimi sürecinde yapılandırdıkları mesleki kimliklerini etkileyen üç temel değişken ortaya çıkmıştır (Şekil 1).

BT Öğretmen Adaylarının Mesleki Kimlik Gelişimleri

\begin{tabular}{|c|c|c|c|c|c|c|}
\hline \multicolumn{2}{|c|}{ BÖTE Öğretim Programı } & \multicolumn{3}{|c|}{ Öğretim Üyeleri } & \multicolumn{2}{|c|}{ Kurumsal Destek } \\
\hline $\begin{array}{l}\text { Alan ve } \\
\text { meslek bilgisi } \\
\text { derslerinin } \\
\text { say1s1 ve } \\
\text { niteliği }\end{array}$ & $\begin{array}{l}\text { Öğretmenlik } \\
\text { uygulamasi } \\
\text { derslerinin } \\
\text { yeterliği }\end{array}$ & $\begin{array}{c}\text { Mesleki } \\
\text { yeterlikleri }\end{array}$ & $\begin{array}{l}\text { Pedagojik } \\
\text { yeterlikleri }\end{array}$ & $\begin{array}{c}\text { Alanı } \\
\text { algilayış } \\
\text { biçimleri }\end{array}$ & $\begin{array}{l}\text { Teknik destek } \\
\text { ve olanaklar }\end{array}$ & $\begin{array}{l}\text { Pedagojik } \\
\text { destek ve } \\
\text { olanaklar }\end{array}$ \\
\hline
\end{tabular}

Şekil 1. Öğretmen eğitimi sürecinde BT öğretmen adaylarının mesleki kimlik yapılarını etkileyen değişkenler

Şekil 1 incelendiğinde öğretmen eğitimi sürecinde, BT öğretmen adaylarının mesleki kimlikleri üzerinde; BÖTE öğretim programının, öğretim üyelerinin ve sağlanan kurumsal desteğin farklı boyutları ile etkisi olduğu görülmektedir. Alanyazında pek çok araştırmada da benzer değişkenlerin öğretmen adaylarının öğretmen eğitimi sürecindeki mesleki kimlik biçimlendirme süreçlerine etkisi belirlenmiştir (Izadinia, 2013; Olsen, 2008; Schepens ve diğ., 2009). Örneğin, Schepens ve diğ. (2009) çalışmalarında; öğretmenlerin öğretmen eğitimi sürecinde mesleki kimliklerinin gelişimini etkileyen değişkenleri CIPP modelini $(\mathrm{C}$-context $=$ bağlam, I-input $=$ girdi, P-process $=$ süreç ve P-product $=$ ürün) temel alarak ortaya koymuştur. $\mathrm{Bu}$ modele göre öğretmen adayları, öğretim bağlamına sahip oldukları girdi değiş̧kenleri (öğretmen eğitimine gelmeden önce sahip olunan inançlar, demografik ve kişisel özellikler, onları bu eğitime yönlendiren güdülenmeler) ile katılmakta, öğretmen eğitimi sürecinde (alınan içerik, destek ve rehberlik, öğretmen olarak gelişimleri için sağlanan işbirliği, öğretmenlik mesleği için hazırlıklar ile) kendilerini geliştirmekte ve öğretmen eğitimi süreci sonunda ürün değişkenlerine 
(öğretimsel yeterlikler, mesleğe uyum ve öğretim işine bağlılık) sahip olmaktadırlar. Alanyazındaki araştırmalardan farklı olarak bu araştırmada öğretmen eğitimi sürecinde mesleki kimliği etkileyen değişkenlerle ilgili olarak öğretim programı; en fazla alan ve meslek bilgisi derslerinin sayısı ve niteliği ve öğretmenlik uygulaması derslerinin yeterliği boyutlarında oldukça tartışılmıştır.

BÖTE programında yıllar içinde yapılan değişiklikler incelendiğinde 1998, 2007 ve 2018 yıllarında Yükseköğretim Kurulu'nun (YÖK) öğretmen yetiştirme lisans programlarındaki düzenlemeleri ile alan, meslek ve genel kültür derslerin sayıs1, dönemi ve okul deneyimi/öğretmenlik uygulaması derslerine yönelik değişiklikler dikkati çekmektedir. BÖTE Bölümü Öğretim Programında yapılan değişiklikler Tablo 6'da yer almaktadir.

Tablo 6

1998, 2007 ve 2018 Yıllarında BÖTE Programında Yapılan Değişiklikler

\begin{tabular}{|c|c|c|c|c|}
\hline & & $\begin{array}{r}1998 \text { Yılı } \\
\text { Lisans } \\
\text { Programı }\end{array}$ & $\begin{array}{c}2007 \text { Yılı } \\
\text { Lisans } \\
\text { Programı }\end{array}$ & $\begin{array}{c}2018 \text { Yilı } \\
\text { Lisans } \\
\text { Programı }\end{array}$ \\
\hline Alan Bilgisi & Toplam saat & 104 & 105 & 87 \\
\hline Dersleri & Ders sayı1 1 & 24 & 26 & 30 \\
\hline Meslek Bilgisi & Toplam saat & 48 & 41 & 54 \\
\hline Dersleri & Ders sayıs1 & 11 & 12 & 21 \\
\hline Genel Kültür- & Toplam saat & 20 & 25 & 25 \\
\hline $\begin{array}{l}\text { Genel Yetenek } \\
\text { Dersleri }\end{array}$ & Ders sayıs1 & 8 & 11 & 11 \\
\hline $\begin{array}{l}\text { Okul Deneyimi } \\
\text { Dersi }\end{array}$ & $\begin{array}{l}\text { Sinıf düzeyi ve } \\
\text { haftalık saati }\end{array}$ & $\begin{array}{l}\text { 1.Sinif- } 5 \text { saat } \\
\text { 4.Sinıf- } 4 \text { saat }\end{array}$ & 4.Sınıf- 5 saat & 4.Sınıf- 8 saat \\
\hline $\begin{array}{l}\text { Öğretmenlik } \\
\text { Uygulaması Dersi }\end{array}$ & Sinıf düzeyi & 4.Sinıf- 8 saat & 4.Sınıf- 8 saat & 4.Sinıf- 8 saat \\
\hline
\end{tabular}

Tablo 6'da görüldüğü gibi, 2007 yllındaki düzenleme ile programdaki meslek bilgisi ders saatleri azaltılmış, alan bilgisi ders saatleri arttırılmıştır. Bunun için 1998 yılı programındaki Kimya, Biyoloji gibi fen bilimleri derslerinin sayıları azaltılmış ve programa o dönemin yeni teknolojileri ile bağlantılı olan Donanım, Veri Tabanı Yönetim Sistemleri ve Proje Yönetimi gibi alan dersleri eklenmiştir. Böylece yeni programdaki alan bilgisi dersi 105 saate yükseltilmiştir. Öte yandan 2007 yılındaki düzenleme ile okul deneyimi dersinin 1. sınıflardan kaldırıldığı ve okul deneyimiöğretmenlik uygulaması ders saatlerinin 17 saatten 13 saate indirildiği dikkati çekmektedir. 11 yıl aynı programın uygulanmasının ardından 2018 yılında alan ders saatleri azaltılsa da ders çeşidi arttırılmış, meslek bilgisi derslerinde ise hem saat hem de ders çeşidi arttırılmıştır. Programa daha çok elektronik ve programlama odaklı algoritma tasarımı ve geliştirme, elektronik devre elemanları, fiziksel programlama ve mobil programlama gibi alan dersleri ile eğitimde ahlak ve etik, eğitim felsefesi ve 
eğitim sosyolojisi gibi meslek dersleri eklenmiştir. Okul deneyimi ve öğretmenlik uygulaması dersleri ise haftada 16 saate çıkarılmıştır.

Öğretmen adaylarının mesleki kimliklerinin oluşmasında, onların mesleği anlamlandırmalarında ve kendilerini etkili ve yeterli bilgi-becerilere sahip öğretmen gibi hissetmelerinde öğretmen eğitimi sürecinde aldıkları öğretmen eğitiminin etkisi oldukça fazladır (Hill, 2017; Hong ve diğ., 2017; Izadinia, 2013). Cochran, DeRuiter ve King'e (1993) göre nitelikli öğretmenler yetiştirmek için sağlam bir alan eğitimi ve meslek eğitimi vermek gerekmektedir. Ne yazık ki BÖTE programı incelendiğinde, programda meslek bilgisi ve alan bilgisi boyutlarında sorunlar olduğu düşünülmektedir. Örneğin, yıllar içinde öğretim programında düzenleme yapılsa da yaklaşık 20 yıldır meslek dersleri ile ilgili kapsamlı bir düzenleme yapılmamışıtır. Aynı meslek bilgisi dersleri ve aynı içerikle öğretmen adayları yetiştirilmeye çalışılmıştır. Yıllarca içeriğinin güncellenmediği ve kaynakların yenilenmediği meslek bilgisi dersleri ile çağımızın gereklerine uygun, yeterli ve nitelikli öğretmenlik becerileri kazanmış adayların yetiştirilmesi olanaklı görülmemektedir.

Öte yandan BÖTE öğretim programının alan bilgisi boyutunda da birtakım sorunlara sahip olduğu düşünülmektedir. Örneğin, teknoloji, yenilik ve değiş̧im odaklı bir bölümde alan derslerindeki güncellemelerin 11 yll gibi uzun bir aradan sonra yapılmış olması nedeni ile öğretmen adaylarının kendilerini alan bilgisi boyutunda yetersiz hissetmeleri şaşırtıcı değildir. Yalnızca bu araştırmada değil BT öğretmen adayları ve BT öğretmenleri ile yapılan araştırmalarda da katılımcıların kendilerini alan bilgisi boyutunda yetersiz hissettikleri ortaya konulmuştur (Özen, Akar ve Horzum, 2017; Yeşiltepe ve Erdoğan, 2013). Bu noktada adayların alan bilgisi boyutunda kendilerini neden yetersiz hissettiklerinin iyi incelenmesi gerekmektedir. Ortaya çıkan mesleki yetersizlik, adayların bireysel ilgi eksikliği ya da yanlıs tercih yapması nedeni ile ortaya çıkabileceği gibi öğretmen eğitimi sürecinde programdaki eksiklikler ya da öğretim üyesi yetersizliği gibi nedenlerden de kaynaklı olabilir. Ancak bilinen o ki yeni teknolojilerden, uygulamalardan ve bunların eğitimdeki hangi sorunlara ne zaman ve nasıl çözüm bulmak için etkili kullanılabileceği konusunda yeterli bilgi ve beceriye sahip olmadan yetişen adayların kendilerini yeterli hissetmeleri olanaklı değildir.

Öte yandan öğretmen eğitimi sürecinde yalnızca teknolojiye, yeniliklere, popüler olan uygulamalara odaklanarak yapılan düzenlemelerin nitelikli BT öğretmenleri yetiştirmek için yeterli olduğu söylenemez. Bu adayların yeni teknolojileri ve uygulamaları öğrenirken temelde öğrenme ve öğretimin nasıl gerçekleştiğini iyi bilmesi, kuramsal ve felsefi bakış açısını kazanmış olması ve meslek bilincine sahip olarak bu uygulamaları kullanmayı ögrenmesi gerekmektedir. $\mathrm{Bu}$ da ancak iyi bir alan bilgisinin yanında iyi bir pedagoji bilgisi, pedagoji-alan bilgisi ve öğretmen eğitimi sürecinde kazanılan nitelikli deneyimle olanaklı görülmektedir.

Özellikle öğretmen olmanın ne anlama geldiği ile ilgili içsel imgelerin ortaya çıkmasında ve adayların kendileri ve konu alanları ile ilgili algılarının yapılanmasında öğretmen eğitimi sürecinde kazanılan deneyimlerin etkisinin oldukça fazla olduğu bir 
gerçektir (Beauchamp ve Thomas, 2009; Chang-Kredl ve Kingsley, 2014; Ezer ve diğ., 2010; Ruohotie-Lyhty ve Moate, 2016). Bu araştırmada BT öğretmen adayları alan bilgisi ile pedagoji bilgisi arasındaki bağı kurmak için deneyimin önemini fark etmiş olacaklar ki mesleki kimlik gelişimini olumsuz etkileyen nedenlerden bir diğeri olarak pedagoji ve alan bilgisini birleştirebilecekleri dersler/uygulamalar ile okuldeneyimi/öğretmenlik uygulaması derslerinin yetersizliğini dile getirmişlerdir. Adayların hâlâ BT öğretmeni olarak okullarda hangi içeriği öğreteceklerini, özlük haklarını, görev tanımlarını, çalışma alanlarını, görev ve sorumluluklarını bilememeleri, uygulamaya dönük eksikliği açık bir biçimde ortaya koymaktadır. Öğretmen adaylarının meslek ile ilgili deneyim kazanmaları nitelikli bir öğretmenlik uygulaması süreci ile olanaklıdır (Korthagen, 2004; Korthagen, Loughran ve Russell, 2006). Bazı derslerde iyi öğretimsel deneyim elde ettiğini belirten adaylar, özellikle süreç içinde mesleki bağlılıklarını, öz-güvenleri ve öz-yeterliklerini geliştirdiklerini vurgulamışlardır. Ancak pek çok alan ve meslek dersinin bu bağı kurmadaki yetersizliği ile okul deneyimi/öğretmenlik uygulaması dersinin yetersizliği nedeni ile BT öğretmenlerinin kim oldukları ile ilgili açık bir fikre sahip olamadıkları, kendilerini öğretmen gibi hissedemedikleri ve gelecekten kaygı duydukları görülmektedir. $\mathrm{Bu}$ sonuçlar, programın adaylarda öğretmen kimliği geliştirmede yetersiz olduğunu ve mesleki deneyim kazandırabilme boyutunda eksik kaldığını bir kez daha ortaya koymaktadır. Tablo 6'da görüldüğü gibi, BÖTE programında uzun yıllar yalnızca son sınıfta haftada 13 saat okul deneyimi ve öğretmenlik uygulaması adlı iki ders ile mesleki deneyimin yeterli düzeyde kazanılabileceği düşünülmemektedir. Alanyazındaki pek çok araştırmada da bu derslerin mesleki kimliğin oluşması bağlamında yeterli olmadığı yıllarca dile getirilmiştir (Aydın ve Akgün, 2014; Becit, Kurt ve Kabakçı, 2009). Adayların okul ortamını, kurulan ilişkileri ve iletişimleri daha fazla deneyimlemeye, yaşayabilecekleri sorunları gözlemlemeye, görev ve sorumluluklarını anlamlandırmaya daha fazla gereksinimleri vardır. Bu konuda 2018 yılındaki program güncellemesinde öğretmenlik uygulaması ders saati haftada 16 saate çıkarılmasına karşın yaşanılan sorunlara 3 saatlik bir artışın yeterli olmayacağı düşünülmektedir. Bu nedenle yeni öğretim programının öğretmen adaylarının kimlik sorunlarını ortadan kaldırma ve gereksinimleri karşılama konusundaki yeterliğinin çok yönlü incelenmesi, yaşanılan sorunlara ne düzeyde çözüm bulduğunun ortaya konulması ve öğrencilerin öğretmenlik deneyimini desteklemek için yapılabileceklerin tartışılması ve uygulamaya konulması gerekmektedir. Bunun için alan derslerinde zaman zaman okul ile işbirliği içinde projeler yürütülmesi, öğrencilere ilk yıllardan başlayarak okul ortamını deneyimleme olanağı sunulması ve öğrencilerin mesleği yürüten öğretmenlerle ilk yıllardan başlayarak daha fazla bir araya gelecekleri çalışmaların yapılması yararlı olabilir.

BT öğretmen adaylarının öğretmen eğitimi sürecinde geliştirdikleri mesleki kimliklerini etkileyen boyutlardan biri de öğretim üyelerdir. Öğretmen eğitimi sürecinde nitelikli öğretmenler yetiştirilebilmesi, öğretim üyelerinin mesleklerinin kuramsal temellerini iyi bilmesi, iyi bir alan bilgisine sahip olması ve adaylara iyi bir rehberlik yapmaları ile olanaklıdır (Goodwin ve diğ., 2014). Bu süreçte öğretim 
üyelerinin üstlendikleri roller, öğretim süreçleri ve kurdukları ilişkiler ile hiç kuşkusuz ki öğretmen adaylarının geliştirdikleri mesleki kimliği de etkilemektedir (Ben-Peretz, Kleeman, Reichenberg ve Shimoni, 2010). Liu ve Fisher'e (2006) göre öğretim üyeleri, adaylara rol model olarak onlara güç ve öz-güven kazandırıp mesleki kimliklerini geliştirebilmenin yanı sıra mesleki kimliklerini engelleyebilmekte, baskı altına alabilmekte ya da sinırlandırabilmektedir. Bu araştırmada da BT öğretmen adayları öğretim üyelerinin alana bakışlarının, alanı algılayış biçimlerinin, mesleki yeterliklerinin, derse hazırlık düzeylerinin ve sahip oldukları mesleki kimliklerin kendilerini ve geliştirdikleri öğretmen kimliğini fazlası ile etkilediğini belirtmişlerdir. Öğretmen adaylarının öğretim üyelerinin özellikle yeterlikleri ya da hazırlıkları ile ilgili yorumları, öğretim üyelerinin gerçekten yetersiz olduğu anlamına gelmese de ortada bir sorun olduğunu göstermektedir. Öte yandan özellikle öğretim üyelerinin alana/mesleğe değer vermediklerini hissettirmeleri, adayları öğretmenlik dışında farklı mesleklere yönlendirmeleri ve öğretim üyeleri ile yeterli iletişim kurmamaları adayların kimlik karmaşası yaşamasına ve neden eğitim fakültesinde olduklarını sorgulamalarına neden olmuştur. Öğretim üyeleri yüzünden pek çok aday duygusal olarak olumsuz etkilenmiş, alana ve mesleğe olan inançlarını kaybetmiş, geleceğe daha karamsar bakmaya başlamışlardır. Öğretim üyelerinin adaylara bu biçimde davranmasının altında pek çok farklı neden olabilir.

BÖTE programındaki öğretim üyelerinin lisans mezuniyetindeki farklılıkları (öğretmenlik programı dışında farklı programlardan mezun olma), alan ve meslek becerilerindeki eksiklikler, kendilerini yeterince geliştirmemeleri, isteksiz olmaları ve mesleki bağlılıklarının olmaması, onların alanı ve mesleği algılayış ve kavrayışlarında, öğrencilerle kurdukları iletişim ve etkileşimlerde farklılıklara neden oluyor olabilir. Ya da üniversitelerde ilgili dersi verecek öğretim üyesi sayısındaki yetersizlikler, öğretim üyelerinin ders yüklerindeki fazlalıklar, atama, yükseltme ve yönetimsel politika sorunları nedeni ile öğretmenlik mesleğinin geleceği olmadığına yönelik sahip oldukları inançlar, çalıştıkları kurumlarda yaşadıkları sorunlar vb. de öğretim üyelerinin mesleki duruşunu etkiliyor olabilir. Örneğin, Van Velzen, Van der Klink, Swennen ve Yaffe'e (2010) göre, öğretim üyelerinin öğretim ile ilgili sorumluklarının yanında araştırma yapma sorumlulukları, artan işyükleri, kurumlarındaki kaynak yetersizliği ve üretken olmayan bir çalışma ortamı öğretim üyelerinin etkililiğini engellemektedir. BÖTE öğretim üyelerinin de bu ve benzer nedenlerden dolayı alanlarına ve mesleklerine bakışları değişiyor, iletişim becerileri olumsuz etkileniyor, mesleki kimlikleri zarar görüyor olabilir. Bu nedenle öğretmen adaylarının mesleki kimliklerini daha istendik bir biçimde yapılandırabilmek için BÖTE öğretim üyelerinin mesleki gelişimlerinin incelenmesi, kimlik gelişimini olumsuz etkileyen durumların belirlenmesi ve öğretim üyelerinin daha verimli bir biçimde çalışabilmeleri için yapılabileceklerin tartışılması yararlı olacaktır. Bu amaçla ülkemizde BÖTE programındaki öğretim üyelerinin yeterliklerini, alana bakışlarını ve mesleki kimliklerini ortaya koyan bir araştırma yapılabilir, öğretim üyelerinin kimlik sorunları ve çözüm önerileri ortaya konulabilir. 
$\mathrm{Bu}$ araştırmada, BT öğretmen adayları öğretmen yetiştirme kurumlarının kendilerine sağladıkları desteği de fazlası ile eleştirmişlerdir. Bilinen o ki öğretmen eğitim kurumlarının hem öğretmen adaylarının hem de öğretim üyelerinin mesleki gelişimlerini sağlayabilmeleri için onları desteklemesi gerekmektedir (CochranSmith, 2003). BÖTE mezunlarının da okullarda teknolojinin etkili ve verimli kullanımı konusunda rehber oldukları düşünüldüğünde, öğretmen eğitimi sürecinde yeni uygulamaları görmeleri, donanım ve yazılım sorunu yaşamamaları, laboratuvar ortamlarını etkili biçimde kullanabilmeleri gerekmektedir. Ancak ne yazık ki BT öğretmen adayları gerek teknik gerekse mesleki boyutta kurumlarından yeterli desteği göremediklerini belirtmiş ve yaşadıkları sorunları dile getirmişlerdir. Halbuki hem adayların hem de öğretim üyelerinin mesleklerini etkili biçimde yürütebilmeleri için kurumlara önemli görevler düşmektedir. Kurum kaynaklı sorunların çözümü için kurumların teknik altyapılarını ve sağladıkları olanakları yeniden gözden geçirmeleri önemlidir. Sürekli güncellenen donanımsal ve yazılımsal gereksinimlerin karşılanmasının yanı sıra adayların hizmetiçi eğitim, kurs, seminer vb. etkinliklerle mesleki gelişimleri daha fazla desteklenebilir.

Öğretmenlerin sahip olduğu mesleki kimlik ve yeterlik hissi, onların mesleği devam ettirmeye ilişkin planlarından, öğretim sürecinde yaşadıkları coşkuya kadar her aşamaya fazlası ile etki etmektedir (Darling-Hammond, Chung ve Frelow, 2002). Öğretmen eğitimi sürecinin de öğretmen adaylarının mesleki kimliklerinin yapılanmasında oldukça etkili olduğu unutulmamalıdır. Önemli olan mesleki kimliğin yapılandığı ve dönüşüme uğradığı bu karmaşık süreçte, güvenli alanlar yaratarak öğretmen adaylarının kendi anlamlandırmaları ile birlikte değerlerini belirlemelerine ve kendi mesleki yaşamlarının mimarı olmalarına destek sağlamaktır. Öğretmen adaylarının yaşadıkları kimlik gelişim sorunları çözümlenmezse ve yeterli destek sağlanmazsa onların meslek yaşantılarındaki kimlik karmaşasını azaltmak kolay olmayacaktır.

\section{Kaynakça}

Alkan, C. (1997). Eğitim teknolojisi. Ankara: Anı Yayıncılık.

Alsup, J. (2006). Teacher identity discourses: Negotiating personal and professional spaces. Mahwah, New Jersey, NJ: Lawrence Erlbaum.

Atal-Köysüren, D. (2016). Ĕ̆itimdeki değişimlerin bilişim teknolojileri ögretmenlerinin mesleki kimlik yapılarl ve duyguları üzerindeki etkisi. (Yayımlanmamış doktora tezi). Ankara Üniversitesi Eğitim Bilimleri Enstitüsü, Ankara.

Atal-Köysüren, D. ve Deryakulu, D. (2017). Eğitim politikalarındaki değişimlerin bilişim teknolojileri öğretmenlerinin duyguları üzerindeki etkisi. Eğitim ve Bilim, 42(190), 67-87. 
Avidov-Ungar, O., and Shamir-Inbal, T. (2017). ICT coordinators' TPACK-based leadership knowledge in their roles as agents of change. Journal of Information Technology Education: Research, 16(1), 169-188.

Aydın, F. ve Akgün, Ö. E. (2014). Eğitim fakültesi BÖTE son sınıf öğrencilerinin okul deneyimi ve öğretmenlik uygulaması derslerinde karşılaştıkları sorunlar. Sakarya Üniversitesi Eğitim Fakültesi Dergisi, (28), 1-14.

Beauchamp, C., and Thomas, L. (2009). Understanding teacher identity: An overview of issues in the literature and implications for teacher education. Cambridge Journal of Education, 39(2), 175-189.

Becit, G., Kurt, A. A. ve Kabakçı, I. (2009). Bilgisayar öğretmen adaylarının okul uygulama derslerinin yararlarına ilişkin görüşleri. Anadolu Üniversitesi Sosyal Bilimler Dergisi, 9(1), 169-184.

Beijaard, D., Meijer, P. C., and Verloop, N. (2004). Reconsidering research on teachers' professional identity. Teaching and Teacher Education, 20(2), 107128.

Ben-Peretz, M., Kleeman, S., Reichenberg, R., and Shimoni, S. (2010). Educators of educators: their goals, perceptions and practices. Professional Development in Education, 36(1-2), 111-129.

Bullough JR, R. V., and Knowles, J. G. (1991). Teaching and nurturing: Changing conceptions of self as teacher in a case study of becoming a teacher. International Journal of Qualitative Studies in Education, 4(2), 121-140.

Bullough, R. V. (1997). Practicing theory and theorizing practice. J. Loughran and T. Russell (Eds.), In Teaching about Teaching (pp. 13-31). London: Falmer Press.

Carter, K., and Doyle, W. (1996). Personal narrative and life history in learning to teach. J. Sikula (Ed.), In Handbook of research on teacher education (2nd ed., pp. 120-142). New York, NY: Simon \& Schuster.

Chang-Kredl, S., and Kingsley, S. (2014). Identity expectations in early childhood teacher education: Pre-service teachers' memories of prior experiences and reasons for entry into the profession. Teaching and Teacher Education, 43, $27-$ 36.

Chong, S., Low, E. L., and Goh, K. C. (2011). Emerging professional teacher identity of pre-service teachers. Australian Journal of Teacher Education, 36(8), 50-64.

Cochran, K. F., DeRuiter, J. A., and King, R. A. (1993). Pedagogical content knowing: An integrative model for teacher preparation. Journal of Teacher Education, 44(4), 263-272.

Cochran-Smith, M. (2003). The multiple meanings of multicultural teacher education: A conceptual framework. Teacher Education Quarterly, 30(2), 7-26. 
Coldron, J., and Smith, R. (1999). Active location in teachers' construction of their professional identities. Journal of Curriculum Studies, 31(6), 711-726.

Darling-Hammond, L., Chung, R., and Frelow, F. (2002). Variation in teacher preparation: How well do different pathways prepare teachers to teach? Journal of Teacher Education, 53(4), 286-302.

Day, C., Elliot, B., and Kington, A. (2005). Reform, standards and teacher identity: Challenges of sustaining commitment. Teaching and Teacher Education, 21(5), 563-577.

Deryakulu, D. (2005). Bilgisayar öğretmenlerinin tükenmişlik düzeylerinin incelenmesi. Eğitim Araştırmaları, 19, 35-53.

Deryakulu, D. (2006). Burnout in Turkish computer teachers: Problems and predictors. International Journal of Educational Reform, 15(3), 370-385.

Deryakulu, D., and Olkun, S. (2007). Analysis of computer teachers' online discussion forum messages about their occupational problems. Educational Technology \& Society, 10(4), 131-142.

Devolder, A., Vanderlinde, R., van Braak, J., and Tondeur, J. (2010). Identifying multiple roles of ICT coordinators. Computers and Education, 55(4), 16511655.

Durak, H. ve Seferoğlu, S. (2017). Öğretmenlerde tükenmişlik duygusunun çeşitli değişkenler açısından incelenmesi. Gazi Üniversitesi Gazi Ĕgitim Fakültesi Dergisi, 37(2), 759-788.

Dursun, F. (2015). Bilişim teknolojileri öğretmenlerinin kendi branşlarına ilişkin metaforik algilarının incelenmesi. E-AJI (Asian Journal of Instruction), 3(1), 6677.

Erdoğan, Y. (2008). Bilgisayar ve öğretim teknolojileri eğitimi bölümü öğrencilerinin mesleki beklentilerinin incelenmesi. Marmara Üniversitesi Ĕgitim Bilimleri Dergisi, 27(1), 135-144.

Eren, E. ve Uluuysal, B. (2012). Bilişim teknolojileri (BT) öğretmenlerinin mesleki sorunları ve çözüm önerileri. Mersin Üniversitesi Eğitim Fakültesi Dergisi, 8(3), 152-171.

Ezer, H., Gilat, I., and Sagee, R. (2010) Perception of teacher education and professional identity among novice teachers, European Journal of Teacher Education, 33(4), 391-404.

Flores, M. A., and Day, C. (2006). Contexts which shape and reshape new teachers' identities: A multi-perspective study. Teaching and Teacher Education, 22(2), 219-232. 
Frazier, M., and Bailey, G. D. (2004). The technology coordinator's handbook. Eugene, Oregon, OR: International Society for Technology in Education.

Gee, J. P. (2000). Identity as an analytic lens for research in education. Review of Research in Education, 25, 99-125.

Geijsel, F., and Meijers, F. (2005). Identity learning: The core process of educational change. Educational Studies, 31(4), 419-430.

Goodwin, A. L., Smith, L., Souto-Manning, M., Cheruvu, R., Tan, M. Y., Reed, R., and Taveras, L. (2014). What should teacher educators know and be able to do? Perspectives from practicing teacher educators. Journal of Teacher Education, 65(4), 284-302.

Hill, S. L. (2017). Exploring the curricular possibilities of pre-Service teacher professional identity. Lyle E. (Ed.), In At the intersection of selves and subject (pp. 105-113). Rotterdam: SensePublishers.

Hong, J. Y. (2010). Pre-service and beginning teachers' professional identity and its relation to dropping out of the profession. Teaching and Teacher Education, 26(8), 1530-1543.

Hong, J., Greene, B., and Lowery, J. (2017). Multiple dimensions of teacher identity development from pre-service to early years of teaching: A longitudinal study. Journal of Education for Teaching, 43(1), 84-98.

Ingersoll, R. M., and Smith, T. M. (2003). The wrong solution to the teacher shortage. Educational Leadership, 60(8), 30-33.

Ivanova, I., and Skara-MincLne, R. (2016). Development of professional identity during teacher's practice. Procedia-Social and Behavioral Sciences, 232, 529536.

Izadinia, M. (2013). A review of research on student teachers' professional identity. British Educational Research Journal, 39(4), 694-713.

Karal, H. ve Timuçin, E. (2010). Bilgisayar ve öğretim teknolojileri öğretmenliği bölümleri mezunların sorunları ve çözüm önerileri. Panel raporu. Kuram ve Uygulamada Eğitim Yönetimi, 16(2), 277-299.

Karataş, S. (2010). Bilgisayar ve öğretim teknolojileri (BÖTE) öğretmen adaylarının mesleklerine ilişkin zihin haritalarının analizi (Gazi Üniversitesi Örneği). Ahi Evran Üniversitesi Eğitim Fakültesi Dergisi, 11(1), 159-173.

Kelchtermans, G. (1993). Getting the story, understanding the lives: From career stories to searchers' professional development. Teaching and Teacher Education, 9(5-6), 443-456. 
Korthagen, F. A. (2004). In search of the essence of a good teacher: Towards a more holistic approach in teacher education. Teaching and Teacher Education, 20(1), 77-97.

Korthagen, F., Loughran, J., and Russell, T. (2006). Developing fundamental principles for teacher education programs and practices. Teaching and Teacher Education, 22(8), 1020-1041.

Lai, K. W., and Pratt, K. (2004). Information and communication technology (ICT) in secondary schools: The role of the computer coordinator. British Journal of Educational Technology, 35(4), 461-475.

Lasky, S. (2005). A sociocultural approach to understanding teacher identity, agency and professional vulnerability in a context of secondary school reform. Teaching and Teacher Education, 21(8), 899-916.

Lindqvist, P., Nordänger, U. K., and Carlsson, R. (2014). Teacher attrition the first five years-A multifaceted image. Teaching and Teacher Education, 40, 94-103.

Liu, Y., and Fisher, L. (2006). The development patterns of modern foreign language student teachers' conceptions of self and their explanations about change: Three cases. Teacher Development, 10(3), 343-360.

Marcovitz, D. M. (2000). The roles of computer coordinators in supporting technology in schools. Journal of Technology and Teacher Education, 8(3), 259273.

Merriam, S. B. (2009). Qualitative research: A guide to design and interpretation. San Francisco, California, CA: Jos-sey-Bass.

Olsen, B. (2008). How reasons for entry into the profession illuminate teacher identity development. Teacher Education Quarterly, 35(3), 23-40.

Önal, N .(2018). Bilişim teknolojileri öğretmen adayları mesleki eğitimleri için neler düşünüyor? Türkiye Sosyal Araştırmalar Dergisi, 22(1), 299-322.

Özen, S., Akar, S. G. M. ve Horzum, M. B. (2017). Farklı BÖTE öğretim programlarında öğrenim gören öğrencilerin sorunları ve mesleki kaygılarının incelenmesi. Çukurova Üniversitesi Eğitim Fakültesi Dergisi, 46(2), 587-602.

Rodgers, C., and Scott, K. (2008). The development of the personal self and professional identity in learning to teach. M. Cochran-Smith, S. Feiman-Nemser, D.J. McIntyre and K.E. Demers (Eds.), In Handbook of research on teacher education: Enduring questions and changing contexts (pp. 732-755). New York, NY: Routledge.

Rodríguez-Miranda, F. P., Pozuelos-Estrada, F. J., and León-Jariego, J. C. (2014). The role of ICT coordinator. Priority and time dedicated to professional functions. Computers and Education, 72, 262-270. 
Ruohotie-Lyhty, M., and Moate, J. (2016). Who and how? Preservice teachers as active agents developing professional identities. Teaching and Teacher Education, 55, 318-327.

Schepens, A., Aelterman, A., and Vlerick, P. (2009). Student teachers’ professional identity formation: Between being born as a teacher and becoming on. Educational Studies, 35(4), 361-378.

Sexton, D. M. (2008). Student teachers negotiating identity, role, and agency. Teacher Education Quarterly, 35(3), 73-88.

Stokking, K., Leenders, F., De Jong, J., and Van Tartwijk, J. (2003). From student to teacher: Reducing practice shock and early dropout in the teaching profession. European Journal of Teacher Education, 26(3), 329-350.

Sugar, W. (2005). Instructional technologist as a coach: Impact of a situated professional development program on teachers' technology use. Journal of Technology and Teacher Education, 13(4), 547-571.

Sugar, W., and Holloman, H. (2009). Technology leaders wanted: Acknowledging the leadership role of a technology coordinator. TechTrends, 53(6), 66-75.

Surry, D. W., and Robinson, M. A. (2001). A taxonomy of instructional technology service positions in higher education. Innovations in Education and Teaching International, 38(3), 231-238.

Sutherland, L., Howard, S., and Markauskaite, L. (2010). Professional identity creation: Examining the development of beginning pre-service teachers' understanding of their work as teachers. Teaching and Teacher Education, 26(3), 455-465.

Şahinkayası, H., Kelleci, Ö. ve Şahinkayası, Y. (2013). Bilişim teknolojileri formatör öğretmenlerin iş doyum düzeyleri: Hatay ili örneği. Gaziantep University Journal of Social Sciences, 12(2), 325-336.

Şerefoğlu-Henkoğlu, H. ve Yıldırım, S. (2012). Türkiye'deki ilköğretim okullarında bilgisayar eğitimi: Kuram ve uygulamadaki farklılıklar. Ankara Üniversitesi Eğitim Bilimleri Fakültesi Dergisi, 45(1), 23-61.

Tennyson, R. D. (2001). Defining core competencies of an instructional technologist. Computers in Human Behavior, 17(4), 355-361.

Topu, F. B. ve Göktaş, Y. (2012). Bilişim teknolojileri öğretmenlerinin üstlendikleri roller ve onlardan beklentiler. Kuram ve Uygulamada Eğitim Bilimleri, 12(1), 461-478.

van Lankveld, T., Schoonenboom, J., Volman, M., Croiset, G., and Beishuizen, J. (2017). Developing a teacher identity in the university context: A systematic review of the literature. Higher Education Research and Development, 36(2), 325-342. 
Van Veen, K., and Sleegers, P. (2006). How does it feel? Teachers' emotions in a context of change. Journal of Curriculum Studies, 38(1), 85-111.

Van Velzen, C., Van der Klink, M., Swennen, A., and Yaffe, E. (2010). The induction and needs of beginning teacher educators. Professional Development in Education, 36(1-2), 61-75.

Walkington, J. (2005). Becoming a teacher: Encouraging development of teacher identity through reflective practice. Asia-Pacific Journal of teacher education, 33(1), 53-64.

Woo, D. (2015). Reviewing and constructing categories for educational technology professionals.International Journal of Education and Development Using Information and Communication Technology, 11(1), 148-163.

Yeşiltepe, G. M. ve Erdoğan, M. (2013). İlköğretim bilişim teknolojileri öğretmenlerinin mesleğe yönelik sorunları, bu sorunların nedenleri ve çözüm önerileri. Gazi Üniversitesi Gazi Eğitim Fakültesi Dergisi, 33(3), 495-530.

Zembylas, M. (2003). Emotions and teacher identity: A poststructural perspective. Teachers and Teaching: Theory and Practice, 9(3), 213-238. 


\title{
Influence of Teacher Education Processes on the Professional Identities of Information and Communication Technologies Teacher Candidates
}

\begin{tabular}{cccc}
\hline ARTICLE TYPE & Received Date & Accepted Date & Published Date \\
Research Article & 01.07 .2019 & 04.30 .2019 & 05.01 .2019 \\
\hline & Deniz Atal iD 1 & \\
Ankara University
\end{tabular}

\begin{abstract}
This study has examined the effects of teacher education processes on professional identity of Information and Communication Technology (ICT) teacher candidates. For this reason, this study has been conducted in basic interpretive qualitative approach which is one of the qualitative research methods. Using the purposeful sampling techniques, participants are ICT teacher candidates, from three universities, 13 from Ankara University, 13 from Hacettepe University and 10 from Gazi University, in Ankara. The study group consists of 12 men, 24 women ICT teacher candidates. Data have been collected through a semi-structured interview form developed by the researcher and have been analyzed using inductive content analysis. As a result of the study, it has been showed that more than half of the ICT teacher candidates could not clearly define the area that they graduated, and themselves as ICT teachers. Moreover, ICT teacher candidates who feel inefficient, insecure and reluctant to pursue their profession think that teacher education is not enough to see themselves as a good ICT teacher. The effectiveness of the courses, communication and interaction with lecturers, school experiences and institutional supports have important effects on professional identities of ICT teacher candidates. Base on the results, recommendations to ICT teacher candidates for graduating without perception of inadequacy and negative professional identity have been discussed.
\end{abstract}

Keywords: Professional identity, teacher education, professional development, ICT teacher candidates.

${ }^{1}$ Corresponding Author: Res. Assist. Dr, Faculty of Educational Science, Department of Computer and Instructional Technology Education, E-mail: atal@ankara.edu.tr, https://orcid.org/0000-0001-8030-9996 


\section{Purpose and Significance}

Over the past decade, technology has become an integral part of the teaching and learning process and a result of this, demands for Information and Communication Technology (ICT) teachers have increased. In literature, there is no specific name for job titles used to describe positions of ICT teachers, they are known as technology coordinator, school librarian or technician. Besides teaching, these teachers are held responsible for some tasks such as providing technical support to other teachers, guiding the integration of technology into schools and maintaining computers and networks. Research studies in the literature show that ICT teachers who are held responsible for extra tasks irrelevant to their teaching profession feel themselves as repairman or service personnel and experience emotional exhaustion stemming from work stress (Atal-Köysüren and Deryakulu, 2017; Deryakulu, 2005; 2006; Deryakulu and Olkun, 2007; Durak and Seferoğlu, 2017; Dursun, 2015; Eren and Uluuysal, 2012; Karal and Timuçin, 2010; Karataş, 2010; Önal, 2018; Şahinkayası, Kelleci and Şahinkayası, 2013; Şerefoğlu-Henkoğlu and Yıldırım, 2012; Topu and Göktaş, 2012). In addition, they have professional identity problems (Atal-Köysüren, 2016).

Teachers' professional identity has emerged as an important topic in teacher education research over the last decade. Similarly, professional identity has been seen as a key factor in beliefs, values and practice of teachers that guide their engagement, commitment, and actions in and out of the classroom (Day, Elliot, and Kington, 2005; Hong, 2010; Korthagen, 2004). Based on the teaching profession, Beijaard, Meijer, and Verloop (2004) identified professional identity as an ongoing process of integration of the personal and the professional sides of becoming a teacher and it is more about how an individual sees herself/himself as a teacher. Although there are lots of factors affecting the construction and interpretation of the professional identity such as leadership, school, educational changes, and reforms; particularly the effect of teacher education on professional identity is debated in the literature over the last decade. Knowing about teacher candidates' identities enables teacher educators to better understand how teacher candidates' identities shape during teacher education programs and which factors positively or negatively impact their professional identity. It also helps teacher educators and curriculum developers in making decisions about how to develop and implement programs so as to enable teacher candidates to go through a productive process of constructing their professional identities (Izadinia, 2013).

The professional identities developed by ICT teacher candidates during teacher education programs constitute the basis of the professional identity that they will develop during their professional lives. In this context, it is necessary to know how ICT teacher candidates develop a professional identity in the process of teacher education and which factors affect their professional identity. Determining the variables that affect ICT teacher candidates' views about their fields and professions and revealing the problems that they experience in the formation of professional identity during the process of teacher education is important in discussing what should be done for a more effective identity development. For this reason, the effects of 
teacher education processes on the professional identity of ICT teacher candidates have been examined in this study.

\section{Method}

This study has been conducted in a basic interpretive qualitative approach which is one of the qualitative research methods. Using the purposeful sampling techniques, participants are ICT teacher candidates, from three universities, 13 from Ankara University, 13 from Hacettepe University and 10 from Gazi University, in Ankara, Turkey. The study group consists of 12 men, 24 women ICT teacher candidates. Data have been collected through a semi-structured interview form developed by the researcher and analyzed with content analysis. The codes and themes have been studied with an expert who is experienced in qualitative research in the educational sciences and holds a Ph.D. degree. The themes have been finalized after the comments and suggestions made one by one. In order to ensure internal and external validity, emerging themes have been presented with direct quotations without comment. The names of the lecturers or faculty members have been presented using three points (...) to ensure privacy and each theme has been described in detail.

\section{Results}

In this research, ICT teacher candidates' views and beliefs about the field and teaching profession have been obtained. Also, variables that affect ICT teacher candidates' professional identity have been determined. According to the findings, none of the interviewed ICT teacher candidates could clearly identify their fields. The field has been defined in a superficial way by using general expressions or with topics such as Scratch and robotic coding that are popular nowadays. When they have been asked who they are as an ICT teacher, ICT teacher candidates have seen themselves as educators $(f=32)$, technician $(f=28)$ and guide $(f=25)$. Additionally, insufficiency about content knowledge ( $f=23$ ), choosing the department unintentionally $(\mathrm{f}=19)$ and lack of interest in the area $(\mathrm{f}=12)$ are the main reasons for why ICT teacher candidates have not felt themselves as an ICT teacher. On the other hand, the professional identity of ICT teacher candidates has been quite affected by course qualities, communication, and interaction with lecturers, school experiences and institutional support factors. According to findings, they have desired to practice their subject matter and pedagogical knowledge in primary schools. However, school experience in high schools, working with a reluctant mentor who could not be a role model for them, or not getting adequate support from academic advisors at university have negative effects on their professional development and their professional identities. Likewise, it is determined that the pedagogical, social and technical support provided by the universities to the ICT teacher candidates during the teacher education process has a significant effect on the quality of the candidates. In this context, especially Instructional Technology (IT) classes, technical infrastructure, software and hardware support have been criticized. It has been emphasized that teacher's profession can be conducted with well-developed and professional efficacy, while it can be limited with a feeling of inadequacy, lack of self-confidence and lack of 
commitment. Not only the quality of the teacher education process but also teacher candidates' reluctance, lack of support for their professional development and demands for all professional knowledge from their lecturers affect their professional identities.

\section{Discussion and Conclusions}

According to the results, it can be seen that the candidates' beliefs about the profession/field, their interests in the profession/field, their reasons for choosing the department and their commitment to the teaching profession have an effect on their professional identities. Before the teacher education process, clearly identifying needs, wishes and expectations and determining priorities are important for ICT teacher candidates to continue their teacher education effectively. In order to solve these problems, which fundamentally influence the development of ICT teacher candidates' professional identity a series of precautions can be taken in this process.

When the Computer and Instructional Technology Education (CITE) curriculum is examined, it is thought that there is a number of problems in pedagogy and field courses in this curriculum. Although some changes have been made in the curriculum over the years, there has not been a comprehensive regulation on pedagogy courses for 20 years and teacher candidates have still been trained with the same content. On the other hand, it is considered that the curriculum of the CITE has some problems in the content knowledge field. For example, it is not surprising that the teacher candidates feel insufficient in their field knowledge because the updates in the field courses were made after a long period of 11 years. For this reason, it is necessary to examine the ability of new curriculum to eliminate the identity problems of ICT teachers/ ICT teacher candidates to meet the requirements of ICT teacher candidates, to find solution to the problems of teacher education and to discuss and implement what can be done to support the ICT teacher candidates' teaching experience. For this purpose, it may be useful to carry out projects in cooperation with the school in the field courses, provide students with the opportunity to experience the school environment starting from the first year and ensure that students work together with the teachers in primary schools from the first year.

In this study, many ICT teacher candidates experience emotional exhaustion stemming from some lecturers' behaviors. There may be many different reasons why lectures behave in this way. The differences in the bachelor degrees of the lecturers (graduating from different programs other than the teaching program), lack of skills in the field, lack of self-development, and lack of professional commitment may cause differences in communication and interactions with students. On the other hand, the inadequacies in the number of lecturers at institution / department, the excess of the courses, the beliefs about the future of the teaching profession, the policy problems due to the appointments and the problems they face in their institutions/department, etc. may also affect the professional positions of lecturers. Therefore, it would be beneficial to examine the professional development of the lecturer, in order to eliminate problems stemming from lecturers and construct ICT teacher candidates' professional identity in a more desirable way. 